\title{
Fate of mercury in tree litter during decomposition
}

\author{
A. K. Pokharel and D. Obrist \\ Desert Research Institute, Division of Atmospheric Sciences, Reno, Nevada, USA \\ Received: 16 February 2011 - Published in Biogeosciences Discuss.: 15 March 2011 \\ Revised: 25 August 2011 - Accepted: 1 September 2011 - Published: 9 September 2011
}

\begin{abstract}
We performed a controlled laboratory litter incubation study to assess changes in dry mass, carbon (C) mass and concentration, mercury $(\mathrm{Hg})$ mass and concentration, and stoichiometric relations between elements during decomposition. Twenty-five surface litter samples each, collected from four forest stands, were placed in incubation jars open to the atmosphere, and were harvested sequentially at $0,3,6,12$, and 18 months. Using a mass balance approach, we observed significant mass losses of $\mathrm{Hg}$ during decomposition (5 to $23 \%$ of initial mass after 18 months), which we attribute to gaseous losses of $\mathrm{Hg}$ to the atmosphere through a gas-permeable filter covering incubation jars. Percentage mass losses of $\mathrm{Hg}$ generally were less than observed dry mass and $\mathrm{C}$ mass losses (48 to $63 \% \mathrm{Hg}$ loss per unit dry mass loss), although one litter type showed similar losses. A field control study using the same litter types exposed at the original collection locations for one year showed that field litter samples were enriched in $\mathrm{Hg}$ concentrations by 8 to $64 \%$ compared to samples incubated for the same time period in the laboratory, indicating strong additional sorption of $\mathrm{Hg}$ in the field likely from atmospheric deposition. Solubility of $\mathrm{Hg}$, assessed by exposure of litter to water upon harvest, was very low ( $<0.22 \mathrm{ng} \mathrm{Hg} \mathrm{g}^{-1}$ dry mass) and decreased with increasing stage of decomposition for all litter types. Our results indicate potentially large gaseous emissions, or re-emissions, of $\mathrm{Hg}$ originally associated with plant litter upon decomposition. Results also suggest that $\mathrm{Hg}$ accumulation in litter and surface layers in the field is driven mainly by additional sorption of $\mathrm{Hg}$, with minor contributions from "internal" accumulation due to preferential loss of $\mathrm{C}$ over $\mathrm{Hg}$. Litter types showed highly species-specific differences in $\mathrm{Hg}$ levels during decomposition suggesting that emissions, retention, and sorption of $\mathrm{Hg}$ are dependent on litter type.
\end{abstract}

Correspondence to: D. Obrist (dobrist@dri.edu)

\section{Introduction}

Atmospheric deposition of mercury ( $\mathrm{Hg})$, a potent neurotoxin, enters remote ecosystems primarily through atmospheric deposition (Fitzgerald et al., 1998; Mason and Sheu, 2002). Terrestrial ecosystems serve as important receptors of $\mathrm{Hg}$ and as sources of $\mathrm{Hg}$ to aquatic systems (Lorey and Driscoll, 1999; Harris et al., 2007), and present large storage pools for atmospheric $\mathrm{Hg}$ depositions which accumulate in surface litter and soil pools (Grigal, 2003). There are several important deposition pathways for atmospheric $\mathrm{Hg}$, including wet deposition resulting from uptake of reactive gaseous $\mathrm{Hg}$ and precipitation scavenging of particulates (Lindberg et al., 1992), plus dry deposition of gaseous elemental, reactive gaseous, and particulate-bound $\mathrm{Hg}$ (Zhang et al., 2009; Fu et al., 2010). Vegetation also plays an important role in deposition of atmospheric Hg (Lindberg, 1996; Grigal, 2003; Driscoll et al., 2007), both through uptake of atmospheric $\mathrm{Hg}$ to leaves and other plant tissues and consecutive input as plant detritus (e.g., litterfall deposition), plus by wash-off of $\mathrm{Hg}$ previously deposited on plant surfaces (i.e., throughfall deposition). A series of field investigations have shown that litterfall alone accounts for 30 to $60 \%$ of total atmospheric $\mathrm{Hg}$ inputs in forests (Schwesig and Matzner, 2000; St. Louis et al., 2001; Rea et al., 2002; Sheehan et al., 2006; Demers et al., 2007) and that leaf litterfall inputs often exceed direct wet deposition inputs by a factor of two or more (Iverfeldt, 1991; Lindberg, 1996; Grigal et al., 2000; St. Louis et al., 2001). Laboratory studies confirm that the main source of $\mathrm{Hg}$ in aboveground biomass is from atmospheric uptake (Ericksen et al., 2003; Frescholtz et al., 2003; Millhollen et al., 2006a, b; Rutter et al., 2011). Field studies show uptake of atmospheric gaseous $\mathrm{Hg}$ during peak vegetation periods, particularly when leaf areas are at maximum expansion (Obrist et al., 2006; Fritsche et al., 2008b). Uptake of Hg by vegetation may occur both through stomatal processes (Ericksen et al., 2003; Stamenkovic and Gustin, 2009; Rutter et al., 2011) and non-stomatal sorption to plant surfaces (Rea et al., 2000; Stamenkovic and Gustin, 2009).

Published by Copernicus Publications on behalf of the European Geosciences Union. 
There are many open questions about the fate and dynamics of $\mathrm{Hg}$ bound to leaves and other plant tissues once tissues are exposed in the environment as litter and in the form of soil organic carbon (C), particularly in regards to potential emission or re-emission fluxes to the atmosphere. Since $\mathrm{Hg}$ in litter and soils is strongly bound to organic matter (Aastrup et al., 1991; Meili, 1991; Grigal, 2003; Obrist et al., 2009), its behavior and mobility is also associated with the dynamics of C (Mierle and Ingram, 1991; Johansson and Iverfeldt, 1994; Joslin, 1994; Driscoll et al., 1995; Lee et al., 1998; Kolka et al., 1999; Grigal, 2002). Organic C also is subject to mineralization, however, and a hypothesized fate of $\mathrm{Hg}$ contained in organic $\mathrm{C}$ includes release from the matrix as C decomposes (Grigal, 2003; Obrist, 2007). A few recent studies indicate correlations between $\mathrm{CO}_{2}$ and $\mathrm{Hg}^{0}$ emission fluxes from soils, indicative of some gaseous losses of $\mathrm{Hg}$ in volatile form upon C mineralization (Wickland et al., 2006; Fritsche et al., 2008a; Obrist et al., 2010), and it has been proposed that $\mathrm{Hg}$ losses from soils may be in the range of a few percent of total $\mathrm{Hg}$ originally bound to organic $\mathrm{C}$ fractions (Obrist et al., 2010).

Exposed surface litter and organic $\mathrm{C}$ pools in the field strongly bind atmospheric $\mathrm{Hg}$ deposition, thereby reducing input and transfer of atmospheric $\mathrm{Hg}$ deposition to water bodies (Harris et al., 2007; Graydon et al., 2009). As a result, field observations generally show strong $\mathrm{Hg}$ enhancement in surface litter and soil organic $\mathrm{C}$ fractions, greatly exceeding $\mathrm{Hg}$ concentrations of the original plant detritus inputs (Lindberg and Harris, 1974; Nater and Grigal, 1992; Hall and St. Louis, 2004; Demers et al., 2007; Tsui et al., 2008; Obrist et al., 2011). Continued sorption of atmospheric $\mathrm{Hg}$ to litter and soil organic $\mathrm{C}$ pools in the field, however, complicates the study of fate of $\mathrm{Hg}$ associated with litter and soil organic $\mathrm{C}$, as newly sorbed $\mathrm{Hg}$ is difficult to separate from $\mathrm{Hg}$ originally associated with plant tissues.

Our goal was to address the fate of $\mathrm{Hg}$ originally bound to forest litter during decomposition under tightly controlled environmental conditions in which we minimized additional $\mathrm{Hg}$ sorption from the atmosphere and from other sources. A set of 25 litter samples each of four different forest litter types were incubated for time periods of $0,3,6,12$, and 18 months. After each period, litter was harvested and analyzed for total $\mathrm{Hg}$, soluble $\mathrm{Hg}, \mathrm{C}, \mathrm{N}$, and dry mass to assess concentration changes and respective mass losses through time. In a field control component, the same litter samples were exposed in surface litter horizons at respective collection sites using litter bags for a period of 12 months. The hypotheses of this study were that (1) during laboratory decomposition, $\mathrm{Hg}$ associated with forest floor litter is subject to gaseous losses as evident by a mass loss of $\mathrm{Hg}$ through time; (2) dry mass and $\mathrm{C}$ mass of litter are preferentially lost compared to $\mathrm{Hg}$ mass, resulting in an increase in $\mathrm{Hg}$ concentrations and $\mathrm{Hg} / \mathrm{C}$ ratio through time; (3) $\mathrm{Hg}$ concentration and $\mathrm{Hg} / \mathrm{C}$ ratio of field control samples will be higher after one year of decomposition compared to samples exposed in the laboratory, re- flecting additional sorption of $\mathrm{Hg}$ in the field (e.g., from atmospheric deposition) ; and (4) $\mathrm{Hg}$ bound to litter also may be subject to mobilization in soluble form during decomposition.

\section{Materials and methods}

\subsection{Litter collection}

We collected fresh surface litter from Oi litter horizons from four different US forest sites: a mixed deciduous forest near Bartlett, New Hampshire; an aspen stand near Reno, Nevada; a pine forest in the Sierra Nevada Mountains near Georgetown, California; and a blue oak forest in the Sierra Nevada foothills near Marysville, California. We will refer to these four different litter types as species throughout the text. The deciduous forest in Bartlett is located at $44^{\circ} 03^{\prime} \mathrm{N}$, and $71^{\circ} 17^{\prime} \mathrm{W}$, at an elevation of $94 \mathrm{~m}$, with annual precipitation of $1270 \mathrm{~mm}$ and mean annual temperature of $4.5^{\circ} \mathrm{C}$. Dominant tree species comprising surface litter at the Bartlett site are American beech (Fagus grandifolia), yellow birch (Betula alleghaniensis), sugar maple (Acer saccharum), and eastern hemlock (Tsuga Canadensis). The aspen stand near Reno, located at a latitude of $39^{\circ} 23^{\prime} \mathrm{N}$, longitude of $119^{\circ} 50^{\prime} \mathrm{W}$, and at an elevation of $1821 \mathrm{~m}$, shows $241 \mathrm{~mm}$ of annual precipitation and a mean annual temperature of $10.5^{\circ} \mathrm{C}$. The dominant aspen species here is Populus tremuloides. The pine forest near Georgetown, California, is located at $38^{\circ} 54^{\prime} \mathrm{N}$ and $120^{\circ} 39^{\prime} \mathrm{W}$, at an elevation of $1302 \mathrm{~m}$, and experiences annual precipitation averaging $1660 \mathrm{~mm}$ and a mean annual temperature of $13.7^{\circ} \mathrm{C}$. Dominant tree species include ponderosa pine (Pinus ponderosa) and sugar pine (Pinus lambertiana), with lesser contributions of white fir (Abies concolor), incense cedar (Calocedrus decurrens), Douglas fir (Pseudotsuga menziesii), and California black oak (Quercus kelloggii). The oak forest in California, dominated by blue oak (Quercus douglasii), is situated at $39^{\circ} 15^{\prime} \mathrm{N}$, and $121^{\circ} 17^{\prime} \mathrm{W}$, is at an elevation of $193 \mathrm{~m}$ and shows annual precipitation of $775 \mathrm{~mm}$ and a mean annual temperature of $16.9^{\circ} \mathrm{C}$. Other species on the site include interior live oak, $(Q$. wislizenii) and foothill pine (Pinus sabiniana).

All sites are considered remote locations not affected by known, specific point sources of $\mathrm{Hg}$. All litter samples were collected within days to a few weeks after the occurrence of leaf litterfall in late summer and fall of 2008. Litter samples were comprised predominantly of leaves from the dominant tree species, with smaller contributions from other trees and from understory vegetation. Woody litter components, which were a minor part of surface litter, were removed from samples in order to facilitate comparison of $\mathrm{Hg}$ patterns in foliar litter across the four sites, and the remaining leaf litter was mixed well (but not crushed) prior to use in the laboratory and field decomposition studies. 


\subsection{Controlled laboratory incubation study}

For the controlled laboratory incubation study, we prepared 100 glass jars of $960 \mathrm{ml}$ volume (wide-mouth, clear USP Type III soda-lime glass with PTFE-lined lids). All glass jars were cleaned with chelating soap and dilute nitric acid (5\%), dried, and weighed. A $2.7 \mathrm{~cm}$ diameter hole was drilled in the lids of the jars and covered with a Teflon ${ }^{\circledR}$ filter membrane (pore size $0.2 \mu \mathrm{m}$ ). This allowed air exchange between the jars and the atmosphere, and, at the same time, avoided deposition of dust (including particulate-bound $\mathrm{Hg}$ ) and likely minimized any transfer and deposition of reactive gaseous $\mathrm{Hg}$ to jars. Each of 25 glass jars was filled with homogenized litter samples from the four sites, with an initial starting weight (fresh mass) of $30 \mathrm{~g}$ of litter ( $15 \mathrm{~g}$ for blue oak litter). Immediately after sample preparation, litter from the first five of the 25 replicate jars was harvested for determination of dry mass and initial $\mathrm{C}, \mathrm{N}$, and $\mathrm{Hg}$ concentrations (i.e., time: $t=0$ month). The 20 remaining jars of each species were placed in an environmentally-controlled chamber at the Desert Research Institute (EcoPODS) at a constant temperature of $25^{\circ} \mathrm{C}$ throughout the experiment. Walls and the ceiling of the chamber were covered by black cloth to allow decomposition under dark conditions. Five replicate glass jars from each species were harvested after 3, 6, 12, and 18 months of incubation (i.e., 4 species $\times 5$ harvest times $\times 5$ replications $=100$ incubation samples total), and analyzed for dry mass, $\mathrm{C}, \mathrm{N}$, and $\mathrm{Hg}$ concentration as described below. Litter samples were kept moist by additions of ultra-purified Millipore water ( $15 \mathrm{ml}$ each) every three weeks. We assured that during harvest, all material from the jars were carefully removed, including small litter fractions that were washed to the bottom of the incubation jars.

We calculated total mass of the respective elements through time. Harvested litter samples also were used for determination of $\mathrm{Hg}$ solubility: ultra-purified Millipore water $(500 \mathrm{~g})$ was added to half of the harvested litter samples, and after one hour of exposure in water, $26.5 \mathrm{ml}$ aliquots of solution were extracted for measurement of soluble $\mathrm{Hg}$. Aliquots were filtered with $0.45 \mu \mathrm{m}$ pore size filters (PTFE membrane; PP housing), preserved by adding $1 \%$ concentrated hydrochloric acid, and stored at $5{ }^{\circ} \mathrm{C}$ until analysis.

\subsection{Field study}

We conducted a field component using the same litter species to assess changes of $\mathrm{Hg}, \mathrm{C}$, and $\mathrm{N}$ concentrations plus their stoichiometric relationships after one year of decomposition. Samples for field decomposition were packed in mash bags made from nylon screen. All bags were washed prior to use with a chelating soap bath for $48 \mathrm{~h}$ and were tested for $\mathrm{Hg}$ concentrations, which averaged $15.0 \pm 7.0 \mu \mathrm{g} \mathrm{Hg} \mathrm{kg}^{-1}$. Hence, mash $\mathrm{Hg}$ concentrations were lower than all litter concentrations observed (see results), and hence litter bags were unlikely a significant source of $\mathrm{Hg}$ to litter in the field.
We measured litter concentrations of $\mathrm{C}, \mathrm{N}$, and $\mathrm{Hg}$ prior to field exposure. Litter bags were exposed in the field for one full year through placement in the surface Oi litter horizons of the respective collection sites. $\mathrm{Hg}, \mathrm{C}$, and $\mathrm{N}$ concentrations were re-measured after collection to assess concentration changes. Mass balances of litter bags were not quantified in the field study due to potential losses of small litter fractions from bags during field exposure and transport. It is important to note that environmental conditions at the field sites differed from those of the controlled laboratory incubation study, including temperatures, rainfall patterns, relative humidities, and solar radiation exposures.

\subsection{Sample analyses for $\mathrm{C}, \mathrm{N}$, total $\mathrm{Hg}$, and soluble $\mathrm{Hg}$}

Upon harvests, litter samples were freeze dried using a freeze dryer (Model Micro Modulyo-115, Thermo Scientific, Waltham, MA, USA) for $48 \mathrm{~h}$. After freeze drying, dry weights of each litter sample contained in glass jars were determined. Half of the well-homogenized litter samples were then milled using stainless steel coffee mills and kept frozen until analysis, while the other portions were used for determination of soluble $\mathrm{Hg}$. Milled samples were analyzed for total Hg using a Model MA-2000 Total Mercury Analyzer (Nippon Inc., Takatsuki, Japan) according to US EPA Method 7473. The analyzer was calibrated using $0.1 \mathrm{ppm}$ and $0.01 \mathrm{ppm} \mathrm{Hg}$ stock solutions made from $1000 \mathrm{ppm} \mathrm{HgCl}_{2}$ standard in $0.001 \%$ L-cysteine solution according to the manufacturer guidelines. National Institute of Standards and Technology (NIST) solid standard reference materials (\# 1575: Pine leaves: $39.9 \mu \mathrm{g} \mathrm{Hg} \mathrm{kg}^{-1}$; and \# 1515: Apple Leaves: $44.4 \mu \mathrm{g} \mathrm{Hg} \mathrm{kg}^{-1}$ ) were measured at the beginning of each analytical run and repeated after every six samples. When analysis of NIST standards deviated more than $5 \%$ from their values, the analyzer was recalibrated and all samples were re-run. Across all sample analyses, NIST standard samples averaged $39.7 \pm 1.2 \mu \mathrm{g} \mathrm{Hg} \mathrm{kg}^{-1}$ (mean \pm standard deviation; $n=27 ; 99 \%$ recovery) for pine leaves, and $44.8 \pm 0.9 \mu \mathrm{g} \mathrm{Hg} \mathrm{kg}^{-1}$ (mean \pm standard deviation; $n=41 ; 101 \%$ recovery) for apple leaves. All samples were analyzed in duplicates, and analyses were repeated when the coefficient of variability of samples exceeded $10 \%$. Total $\mathrm{C}$ and $\mathrm{N}$ in litter samples were analyzed using a Leco Turspec carbon/nitrogen analyzer (LECO, St. Joseph, Michigan, USA) at the Soil Forage and Water Analysis Laboratory at Oklahoma State University (http://www.soiltesting. okstate.edu/), which guarantees accuracy and precision of test results through daily analysis of quality control samples. All instruments used for analysis were calibrated with certified standards and maintained in accordance with specification. Using standards every 10 samples, specific quality control for $\mathrm{C} / \mathrm{N}$ analysis included frequent blank test and sample checks.

Water samples for determination of soluble $\mathrm{Hg}$ were analyzed according to US EPA Method 1631 for Total Mercury 
Table 1. Dry mass, $\mathrm{C}$ mass, $\mathrm{C}$ concentration, $\mathrm{Hg}$ concentration, $\mathrm{Hg}$ mass, $\mathrm{Hg} / \mathrm{C}$ ratio, $\mathrm{N}$ mass, $\mathrm{N}$ concentration, $\mathrm{C} / \mathrm{N}$ ratio, and $\mathrm{Hg} / \mathrm{N}$ ratio of laboratory samples.

\begin{tabular}{|c|c|c|c|c|c|c|c|c|c|c|c|c|}
\hline \multirow{2}{*}{$\begin{array}{l}\text { Time in } \\
\text { months }\end{array}$} & \multicolumn{4}{|c|}{ Dry mass (g) } & \multicolumn{4}{|c|}{$\mathrm{C}$ mass $(\mathrm{g})$} & \multicolumn{4}{|c|}{$\mathrm{C}$ concentration $(\%)$} \\
\hline & $\begin{array}{r}\text { Mixed } \\
\text { deciduous }\end{array}$ & Aspen & Pine & Oak & $\begin{array}{r}\text { Mixed } \\
\text { deciduous }\end{array}$ & Aspen & Pine & Oak & $\begin{array}{c}\text { Mixed } \\
\text { deciduous }\end{array}$ & Aspen & Pine & Oak \\
\hline 0 & $24.1 \pm 0.4$ & $23.9 \pm 0.3$ & $21.3 \pm 0.6$ & $11.1 \pm 1.2$ & $11.7 \pm 0.3$ & $11.3 \pm 1.0$ & $10.8 \pm 0.3$ & $5.3 \pm 0.6$ & $48.6 \pm 0.7$ & $47.3 \pm 0.5$ & $50.8 \pm 0.5$ & $47.9 \pm 0.1$ \\
\hline 3 & $22.2 \pm 0.5$ & $22.5 \pm 0.9$ & $20.9 \pm 0.4$ & $10.6 \pm 1.1$ & $11.0 \pm 0.1$ & $10.2 \pm 0.4$ & $10.6 \pm 0.3$ & $5.1 \pm 0.6$ & $49.7 \pm 0.5$ & $45.5 \pm 0.8$ & $50.7 \pm 0.4$ & $48.2 \pm 0.6$ \\
\hline 6 & $21.8 \pm 0.5$ & $21.3 \pm 0.4$ & $20.6 \pm 0.4$ & $10.4 \pm 1.2$ & $10.9 \pm 0.2$ & $10.2 \pm 0.2$ & $9.3 \pm 0.2$ & $4.4 \pm 0.5$ & $50.3 \pm 0.4$ & $47.7 \pm 0.2$ & $45.0 \pm 0.5$ & $42.5 \pm 0.6$ \\
\hline 12 & $19.9 \pm 0.5$ & $16.8 \pm 1.0$ & $19.9 \pm 0.5$ & $9.5 \pm 0.6$ & $9.5 \pm 0.2$ & $7.7 \pm 0.5$ & $9.7 \pm 0.2$ & $4.4 \pm 0.3$ & $47.7 \pm 0.4$ & $45.7 \pm 0.3$ & $48.9 \pm 0.3$ & $46.2 \pm 0.4$ \\
\hline \multirow[t]{3}{*}{18} & $19.4 \pm 0.3$ & $16.4 \pm 0.9$ & $19.7 \pm 0.6$ & $8.6 \pm 0.7$ & $9.6 \pm 0.2$ & $7.5 \pm 0.5$ & $10.1 \pm 0.3$ & $4.1 \pm 0.3$ & $49.6 \pm 0.4$ & $45.9 \pm 0.6$ & $51.3 \pm 0.5$ & $47.4 \pm 0.8$ \\
\hline & \multicolumn{4}{|c|}{$\mathrm{Hg}$ concentration $\left(\mu \mathrm{g} \mathrm{kg}^{-1}\right)$} & \multicolumn{4}{|c|}{ Hg mass (ng) } & \multicolumn{4}{|c|}{$\mathrm{Hg} / \mathrm{C}$ ratio $\left(\mu \mathrm{g} \mathrm{kg}^{-1} \mathrm{C}\right)$} \\
\hline & $\begin{array}{r}\text { Mixed } \\
\text { deciduous }\end{array}$ & Aspen & Pine & Oak & $\begin{array}{r}\text { Mixed } \\
\text { deciduous }\end{array}$ & Aspen & Pine & Oak & $\begin{array}{c}\text { Mixed } \\
\text { deciduous }\end{array}$ & Aspen & Pine & Oak \\
\hline 0 & $32.4 \pm 4.2$ & $50.2 \pm 1.6$ & $39.3 \pm 2.5$ & $40.7 \pm 1.5$ & $782 \pm 97$ & $1198 \pm 30$ & $834 \pm 57$ & $452 \pm 48$ & $66.8 \pm 8.9$ & $106.1 \pm 3.3$ & $77.4 \pm 5.6$ & $84.9 \pm 3.3$ \\
\hline 3 & $35.5 \pm 1.7$ & $54.6 \pm 1.5$ & $37.9 \pm 3.0$ & $40.8 \pm 1.2$ & $788 \pm 53$ & $1228 \pm 52$ & $792 \pm 61$ & $430 \pm 37$ & $71.5 \pm 4.0$ & $119.9 \pm 5.0$ & $74.8 \pm 6.3$ & $84.8 \pm 2.6$ \\
\hline 6 & $35.0 \pm 3.4$ & $55.1 \pm 2.9$ & $38.4 \pm 2.3$ & $36.1 \pm 1.8$ & $764 \pm 71$ & $1174 \pm 44$ & $790 \pm 46$ & $378 \pm 55$ & $69.7 \pm 7.3$ & $115.6 \pm 6.3$ & $85.3 \pm 5.0$ & $84.9 \pm 3.9$ \\
\hline 12 & $34.9 \pm 2.1$ & $61.8 \pm 3.1$ & $37.9 \pm 1.8$ & $39.0 \pm 2.7$ & $700 \pm 62$ & $1036 \pm 52$ & $754 \pm 42$ & $372 \pm 24$ & $73.2 \pm 5.0$ & $135.3 \pm 7.4$ & $77.5 \pm 3.7$ & $84.4 \pm 5.2$ \\
\hline \multirow[t]{3}{*}{18} & $35.5 \pm 1.6$ & $62.1 \pm 5.0$ & $40.3 \pm 3.8$ & $40.3 \pm 3.8$ & $690 \pm 26$ & $1016 \pm 31$ & $792 \pm 84$ & $348 \pm 36$ & $71.7 \pm 3.5$ & $135.6 \pm 12.2$ & $78.6 \pm 7.5$ & $84.9 \pm 9.0$ \\
\hline & \multicolumn{4}{|c|}{$\mathrm{N}$ mass $(\mathrm{g})$} & \multicolumn{4}{|c|}{$\mathrm{N}$ concentration $(\%)$} & \multicolumn{4}{|c|}{$\mathrm{C} / \mathrm{N}$ ratio } \\
\hline & $\begin{array}{r}\text { Mixed } \\
\text { deciduous }\end{array}$ & Aspen & Pine & Oak & $\begin{array}{r}\text { Mixed } \\
\text { deciduous }\end{array}$ & Aspen & Pine & Oak & $\begin{array}{c}\text { Mixed } \\
\text { deciduous }\end{array}$ & Aspen & Pine & Oak \\
\hline 0 & $0.13 \pm 0.01$ & $0.16 \pm 0.013$ & $0.09 \pm 0.01$ & $0.09 \pm 0.01$ & $0.56 \pm 0.05$ & $0.67 \pm 0.06$ & $0.45 \pm 0.03$ & $0.81 \pm 0.05$ & $87.8 \pm 8.7$ & $70.6 \pm 5.7$ & $113.3 \pm 6.7$ & $59.2 \pm 3.4$ \\
\hline 3 & $0.14 \pm 0.01$ & $0.17 \pm 0.013$ & $0.08 \pm 0.01$ & $0.09 \pm 0.01$ & $0.64 \pm 0.03$ & $0.74 \pm 0.04$ & $0.39 \pm 0.03$ & $0.83 \pm 0.09$ & $77.6 \pm 4.4$ & $62.1 \pm 4.5$ & $130.8 \pm 8.8$ & $58.7 \pm 6.9$ \\
\hline 6 & $0.12 \pm 0.01$ & $0.16 \pm 0.012$ & $0.08 \pm 0.01$ & $0.08 \pm 0.01$ & $0.56 \pm 0.04$ & $0.77 \pm 0.07$ & $0.41 \pm 0.05$ & $0.80 \pm 0.05$ & $89.4 \pm 7.7$ & $62.4 \pm 5.2$ & $111.2 \pm 13.8$ & $53.0 \pm 4.1$ \\
\hline 12 & $0.13 \pm 0.02$ & $0.17 \pm 0.012$ & $0.09 \pm 0.00$ & $0.08 \pm 0.01$ & $0.65 \pm 0.06$ & $1.00 \pm 0.09$ & $0.43 \pm 0.02$ & $0.86 \pm 0.06$ & $73.8 \pm 6.5$ & $45.9 \pm 3.9$ & $114.4 \pm 5.3$ & $54.1 \pm 3.5$ \\
\hline \multirow[t]{3}{*}{18} & $0.21 \pm 0.01$ & $0.23 \pm 0.01$ & $0.16 \pm 0.01$ & $0.12 \pm 0.02$ & $1.07 \pm 0.03$ & $1.40 \pm 0.12$ & $0.83 \pm 0.05$ & $1.35 \pm 0.19$ & $46.2 \pm 1.4$ & $33.2 \pm 3.0$ & $61.8 \pm 3.3$ & $35.9 \pm 5.8$ \\
\hline & \multicolumn{4}{|c|}{$\mathrm{Hg} / \mathrm{N}$ ratio $\left(\mu \mathrm{g} \mathrm{kg}^{-1} \mathrm{~N}\right)$} & & & & & & & & \\
\hline & $\begin{array}{r}\text { Mixed } \\
\text { deciduous }\end{array}$ & Aspen & Pine & Oak & & & & & & & & \\
\hline 0 & $5809 \pm 378$ & $7481 \pm 592$ & $8754 \pm 701$ & $5027 \pm 335$ & & & & & & & & \\
\hline 3 & $5542 \pm 340$ & $7434 \pm 364$ & $9749 \pm 582$ & $4963 \pm 464$ & & & & & & & & \\
\hline 6 & $6195 \pm 383$ & $7188 \pm 168$ & $9434 \pm 632$ & $4498 \pm 348$ & & & & & & & & \\
\hline 12 & $5386 \pm 337$ & $6193 \pm 215$ & $8850 \pm 375$ & $4552 \pm 307$ & & & & & & & & \\
\hline 18 & $3313 \pm 185$ & $4475 \pm 187$ & $4836 \pm 220$ & $3019 \pm 334$ & & & & & & & & \\
\hline
\end{tabular}

in Water using dual stage gold pre-concentration. We used a Tekran 2600 Mercury Analyzer (Tekran Inc., Toronto, Canada). Bromine monochloride $(0.5 \% \mathrm{BrCl})$ was added to each sample $12 \mathrm{~h}$ prior to analysis for sample digestion. Immediately prior to sample analysis, we added $0.25 \%$ hydroxylamine hydrochloride $(\mathrm{HH})$ to samples to ensure full destruction of the free halogens. We used a $3 \%$ solution of freshly prepared stannous chloride, purged with a slow flow of ultra-high purity (UHP) argon at $20 \mathrm{ml} \mathrm{min}^{-1}$, to reduce $\mathrm{Hg}$ in samples to gaseous $\mathrm{Hg}$, which was separated by a liquid-gas separator and loaded on gold traps of the analyzer. After thermal desorption, $\mathrm{Hg}$ was analyzed using atomic fluorescence spectroscopy. The analyzer was calibrated with standards of $0.5,5,10,25$, and $50 \mathrm{ppt}$ of $\mathrm{Hg}$ in solution of $0.5 \% \mathrm{BrCl}$, and $0.25 \% \mathrm{HH}$. Quality control included three calibration blanks (consisting of $0.5 \% \mathrm{BrCl}$ and $0.25 \% \mathrm{HH}$ reagent), Ongoing Precision and Recovery (OPR) of $5 \mathrm{ppt} \mathrm{Hg}$ after every six samples (average recovery $97 \pm 9 \% ; n=21$ ), and matrix spikes of at least two samples per analytical run. Detection limit of the system was estimated at $<0.5 \mathrm{ppt}$, based on $3 \times$ standard deviation of the reagent blanks.

\subsection{Statistical analyses}

All numbers in text, figures, and tables (Table 1) are shown as mean \pm 1 standard deviation of five replicate samples for the laboratory study, and mean \pm 1 standard deviation of 15 replicate samples for the field study. Statistical analyses of laboratory samples (Table 2) were performed using analysis of variance (ANOVA) and Bonferroni post-hoc comparison tests to analyze for statistical effects of variables: Time, Species, and Time $\times$ Species interactions. Dependent variables tested were dry mass, $\mathrm{C}$ mass, $\mathrm{C}$ concentrations, $\mathrm{Hg}$ mass, $\mathrm{Hg}$ concentrations, $\mathrm{Hg} / \mathrm{C}$ ratio, $\mathrm{C} / \mathrm{N}$ ratios, and total soluble $\mathrm{Hg}$ (per unit dry mass). We performed Bonferroni post-hoc tests when the significant Time $\times$ Species interactions indicated different time trends among species to assess which of the species showed statistical changes. For field litter samples, paired Student t-tests were performed to assess differences in $\mathrm{Hg}$ concentrations, $\mathrm{Hg} / \mathrm{C}$ ratios, and $\mathrm{C} / \mathrm{N}$ ratios prior to and after exposure. Linear regression analyses were performed to assess the relationships of $\mathrm{Hg}$ concentrations and respective $\mathrm{C} / \mathrm{N}$ ratios (Fig. 3). All statistical tests were performed with STATA Version 9 (Stata Corporation, 
Table 2. Results of statistical Analysis Of Variance (ANOVA) and Bonferroni post-hoc tests to test for effects of incubation time (continuous variable), species (categorical variable), and interactions for the dependent variables: dry mass, $\mathrm{Hg}$ mass, $\mathrm{Hg}$ concentration, $\mathrm{Hg} / \mathrm{C}$ ratio, $\mathrm{C}$ mass, $\mathrm{C}$ concentration, $\mathrm{C} / \mathrm{N}$ ratio, $\mathrm{N}$ mass, $\mathrm{N}$ concentration, and soluble $\mathrm{Hg}$.

\begin{tabular}{|c|c|c|c|c|c|c|c|c|c|}
\hline & & \multicolumn{8}{|c|}{ Dependent Variables } \\
\hline & & $\begin{array}{l}\text { Dry mass } \\
(\mathrm{g})\end{array}$ & $\begin{array}{l}\mathrm{Hg} \text { mass } \\
(\mathrm{ng})\end{array}$ & $\begin{array}{l}\mathrm{Hg} \text { concentration } \\
\left(\mu \mathrm{g} \mathrm{kg}^{-1}\right)\end{array}$ & $\mathrm{Hg} / \mathrm{C}$ ratio & $\begin{array}{l}\mathrm{C} \text { mass } \\
(\mathrm{g})\end{array}$ & $\begin{array}{l}\mathrm{C} \text { concentration } \\
(\%)\end{array}$ & $\mathrm{C} / \mathrm{N}$ ratio & $\begin{array}{l}\text { Soluble } \mathrm{Hg} \\
\text { (ng g }{ }^{-1} \text { dry mass) }\end{array}$ \\
\hline $\begin{array}{l}\text { ANOVA } \\
\text { tests }\end{array}$ & $\begin{array}{l}\text { Variable Time } \\
\text { Variable Species } \\
\text { Interaction Time } \\
\times \text { Species }\end{array}$ & $\begin{array}{l}\mathrm{DF}=1, P<0.01 \\
\mathrm{DF}=3, P<0.01 \\
\mathrm{DF}=3, P<0.01\end{array}$ & $\begin{array}{l}\mathrm{DF}=1, P<0.01 \\
\mathrm{DF}=3, P<0.01 \\
\mathrm{DF}=3, P<0.01\end{array}$ & $\begin{array}{l}\mathrm{DF}=1, P<0.01 \\
\mathrm{DF}=3, P<0.01 \\
\mathrm{DF}=3, P<0.01\end{array}$ & $\begin{array}{l}\mathrm{DF}=1, P<0.01 \\
\mathrm{DF}=3, P<0.01 \\
\mathrm{DF}=3, P<0.01\end{array}$ & $\begin{array}{l}\mathrm{DF}=1, P<0.01 \\
\mathrm{DF}=3, P<0.01 \\
\mathrm{DF}=3, P<0.01\end{array}$ & $\begin{array}{l}\mathrm{DF}=1, P=0.64 \\
\mathrm{DF}=3, P<0.01 \\
\mathrm{DF}=3, P=0.64\end{array}$ & $\begin{array}{l}\mathrm{DF}=1, P<0.01 \\
\mathrm{DF}=3, P<0.01 \\
\mathrm{DF}=3, P<0.01\end{array}$ & $\begin{array}{l}\mathrm{DF}=1, P<0.01 \\
\mathrm{DF}=3, P<0.01 \\
\mathrm{DF}=3, P<0.01\end{array}$ \\
\hline $\begin{array}{l}\text { Bonferroni } \\
\text { tests }\end{array}$ & $\begin{array}{l}\text { Significant effect } \\
\text { of Time in }\end{array}$ & $\begin{array}{l}\text { Mixed Deciduous } \\
\text { Aspen Pine Oak }\end{array}$ & $\begin{array}{l}\text { Mixed Deciduous } \\
\text { Aspen Oak* }\end{array}$ & Aspen & Aspen & $\begin{array}{l}\text { Mixed Deciduous } \\
\text { Aspen Pine Oak }\end{array}$ & N/A & $\begin{array}{l}\text { Mixed Deciduous } \\
\text { Aspen Pine Oak }\end{array}$ & $\begin{array}{l}\text { Mixed Deciduous } \\
\text { Aspen Oak }\end{array}$ \\
\hline
\end{tabular}

* Significant post-hoc test at significance level $=0.10$, but not at 0.05 .

College Station, Texas, USA). We considered statistically significant effects when $P$-values were lower than 0.05 .

\section{Results}

\subsection{Laboratory decomposition study: $\mathrm{Hg}, \mathrm{C}$, and $\mathrm{N}$ concentration and mass changes}

At the start of the experiment, initial litter dry mass across all jars were $24.1 \pm 0.4 \mathrm{~g}$ in mixed deciduous litter, $23.9 \pm$ $0.3 \mathrm{~g}$ in aspen litter, $21.3 \pm 0.6 \mathrm{~g}$ in pine needle litter, and $11.1 \pm 1.2 \mathrm{~g}$ in oak leaves (Fig. 1; Table 1). In all four litter species, changes in dry mass showed relatively consistent temporal trends with increasing time of incubation. Pine needle litter showed small mass losses with each subsequent time interval, averaging 2, 3, 7, and $8 \%$ loss of the initial (i.e., 0 month) dry mass after 3, 6, 12, and 18 months of incubation, respectively. All other litter types showed more substantial mass losses with time: dry mass decreased by 8 , 10,17 , and $19 \%$ in mixed deciduous litter and by $6,11,30$, and $31 \%$ in aspen litter. We also observed similar mass reductions in oak litter accounting for 5, 7, 15, and $22 \%$ loss of initial mass. ANOVA tests (Table 2) including data of all litter species showed significant effects of Time, Species, and Time $\times$ Species interactions on dry mass, indicative of significant mass losses in time across all samples. Bonferroni post-hoc tests following the ANOVA showed that a significant effect of Time was evident in all four litter species.

Associated with dry mass losses, we observed $\mathrm{C}$ mass losses (Fig. 1; Table 1) with increasing time of incubation, and $\mathrm{C}$ mass losses were in a similar range as those observed for dry mass. Mass losses of $\mathrm{C}$, however, were less consistent in time, likely due to sample variability of $\mathrm{C}$ analyses. Similar to dry mass, ANOVA tests showed significant effects of Time, Species, and Time $\times$ Species interactions on C mass across all litter samples, and Bonferroni post-hoc tests also showed that the significant effect of Time occurred in all four litter species.
The similar behavior of dry mass and $\mathrm{C}$ mass losses was due to relatively constant $\mathrm{C}$ concentrations in time (Fig. 1; Table 1). Small, inconsistent, and not statistically significant changes in $\mathrm{C}$ concentrations by the end of the experiment (after 18 months) included an increase of $2 \%$ and $1 \%$ in mixed deciduous and pine litter as well as a decrease by $3 \%$ and $1 \%$ in aspen and oak litter. ANOVA tests on C concentrations showed a significant effect of Species, but no significant effect of Time.

Initial Hg concentrations (i.e., 0 month; Fig. 2; Table 1) in litter samples averaged $32.4 \pm 4.2 \mu \mathrm{g} \mathrm{kg}^{-1}$ in mixed deciduous litter, $50.2 \pm 1.6 \mu \mathrm{g} \mathrm{kg}^{-1}$ in aspen litter, $39.3 \pm$ $2.5 \mu \mathrm{g} \mathrm{kg}^{-1}$ in pine litter, and $40.7 \pm 1.5 \mu \mathrm{g} \mathrm{kg}^{-1}$ in oak litter. Using all data, ANOVA tests showed statistically significant effects of Time, Species, and Time $\times$ Species interaction on $\mathrm{Hg}$ concentration. Changes in $\mathrm{Hg}$ concentrations, however, were highly species-specific: Bonferroni post-hoc tests showed that the Time effect was driven solely by one species, aspen litter, which showed a strong increase in Hg concentration through time. All other species showed no significant Time effects on $\mathrm{Hg}$ concentrations using Bonferroni post-hoc tests. $\mathrm{Hg}$ concentration in aspen litter increased by $24 \%$ after 18 months of incubation, but $\mathrm{Hg}$ concentrations remained within 1 to $10 \%$ of the original concentrations for the other three species.

Total Hg mass contained in incubation jars (Fig. 2; Table 1), calculated by multiplication of $\mathrm{Hg}$ concentrations by dry mass, averaged $782 \pm 97 \mathrm{ng}, 1198 \pm 30 \mathrm{ng}, 834 \pm 57 \mathrm{ng}$, and $452 \pm 48 \mathrm{ng}$ at the start of the experiment for mixed deciduous, aspen, pine, and oak litter, respectively. After 18 months of incubation, $\mathrm{Hg}$ mass was reduced by $92 \mathrm{ng}$, $182 \mathrm{ng}, 42 \mathrm{ng}$, and $104 \mathrm{ng}$ in mixed deciduous, aspen, pine, and oak litter, respectively. These $\mathrm{Hg}$ mass losses accounted for 5 to $23 \%$ of the initial $\mathrm{Hg}$ mass present at the start of the incubation. ANOVA tests including all data showed significant effects of Time, Species, and Time $\times$ Species interactions, indicative of significant mass losses of $\mathrm{Hg}$ across all litter samples. $\mathrm{Hg}$ mass losses were species-specific, and Bonferroni post-hoc tests showed that the significant effect of Time was driven by significant $\mathrm{Hg}$ mass losses in mixed 
A Dry mass

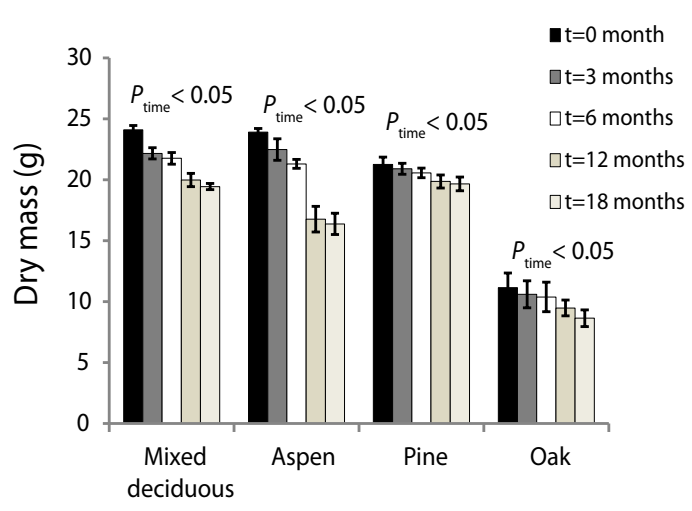

Litter Species

\section{B C mass}

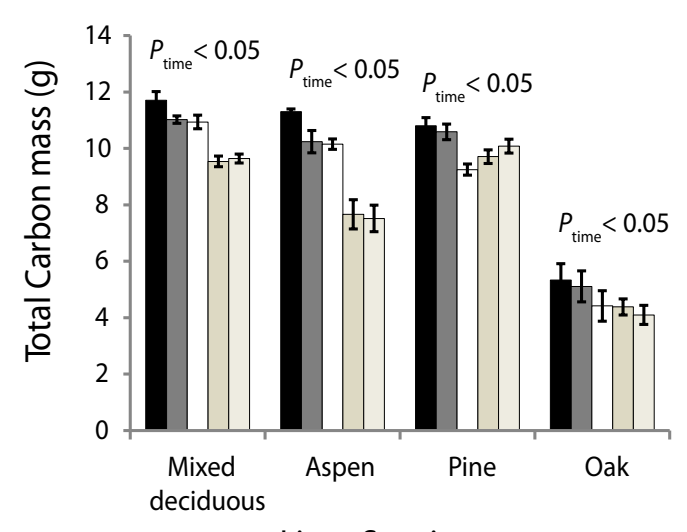

Litter Species

\section{C concentration}

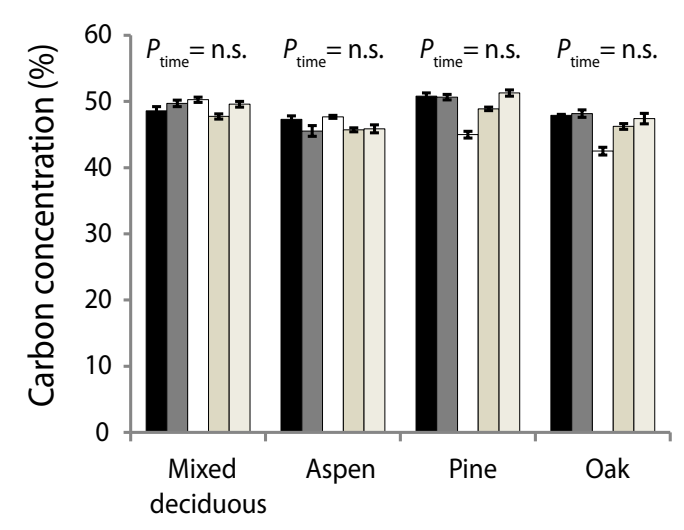

Litter Species

Fig. 1. Development of dry mass, carbon (C) mass, and C concentrations throughout 18 months of litter decomposition in a controlled laboratory study. Bars represent means \pm standard deviations of five replicate samples. $P$-values are effects of Time for individual species based on Bonferroni post-hoc analyses (Table 2). deciduous litter, aspen litter, and to a smaller degree in oak litter (at the $10 \%$ significance level). No Time effect, based on Bonferroni post-hoc tests, was observed for $\mathrm{Hg}$ mass in pine litter.

\subsection{Stoichiometric relationships between $\mathrm{Hg}, \mathrm{C}$, and $\mathrm{N}$}

$\mathrm{Hg} / \mathrm{C}$ ratios showed only minor changes during the 18 months of laboratory decomposition in most litter species (Fig. 2; Table 1). Overall, ANOVA tests showed significant effects of Time, Species, and Time $\times$ Species interaction on $\mathrm{Hg} / \mathrm{C}$ ratios. As with $\mathrm{Hg}$ concentrations, the significant increase in $\mathrm{Hg} / \mathrm{C}$ ratios, however, was driven entirely by aspen as indicated by Bonferroni post-hoc tests, while no significant Time effect was evident for the other three litter species. In aspen, $\mathrm{Hg} / \mathrm{C}$ ratios increased from $106.1 \pm 3.3 \mu \mathrm{g} \mathrm{kg}^{-1} \mathrm{C}$ at the start of the experiment to $135.6 \pm 12.2 \mu \mathrm{g} \mathrm{kg}^{-1} \mathrm{C}$ at the end of the experiment.

In regards to $\mathrm{C} / \mathrm{N}$ ratios, ANOVA tests showed significant effects of Time, Species, and Time $\times$ Species interaction, in support of decreases in $\mathrm{C} / \mathrm{N}$ ratios in time across all laboratory samples. Post-hoc Bonferroni tests showed that the Time effects were significant in all four litter species, although occurring to various degrees. Regression analyses between $\mathrm{Hg}$ concentrations and $\mathrm{C} / \mathrm{N}$ ratios in laboratory samples (Fig. 3c) showed significant increase in $\mathrm{Hg}$ concentrations with decreasing $\mathrm{C} / \mathrm{N}$ ratios in aspen and pine litter samples (significant negative slope of linear regression; $r^{2}=0.77$ and $r^{2}=0.22$, respectively), while the two other litter species showed no significant regression slopes.

\subsection{Field litter decomposition patterns}

Paired Student $\mathrm{t}$-tests of $\mathrm{Hg}$ concentrations of samples prior to and after exposure for one full year in the field showed that $\mathrm{Hg}$ concentration increased significantly across all species. When each species was analyzed independently, three of four showed significant $\mathrm{Hg}$ concentration increases after field exposure, and only in pine litter was the effect not statistically significant. Increases in $\mathrm{Hg}$ concentrations during the oneyear field exposure (i.e., from time $t=0$ month to time $t=12$ months, Fig. 3a) accounted for $23 \mu \mathrm{g} \mathrm{kg}^{-1}$ in mixed deciduous (+67\%), $15 \mu \mathrm{g} \mathrm{kg}^{-1}$ in aspen (+28\%), and $21 \mu \mathrm{g} \mathrm{kg}^{-1}$ in oak $(+62 \%)$ compared to concentrations of the samples prior to the field exposure. Final concentrations of $\mathrm{Hg}$ in the field (i.e., after one year of exposure) were higher in all litter types compared to the concentrations after laboratory exposure for one year $(+64 \%$ in mixed deciduous, $+62 \%$ in oak, $+10 \%$ in aspen, and $+8 \%$ in pine). However, given that field decomposition likely proceeded at different rates than decomposition in the laboratory, we analyzed $\mathrm{Hg}$ concentrations as a function of $\mathrm{C} / \mathrm{N}$ ratios to standardize $\mathrm{Hg}$ concentrations to the degree of decomposition. $\mathrm{C} / \mathrm{N}$ ratios can be used as a proxy for the degree of litter decomposition with generally decreasing $\mathrm{C} / \mathrm{N}$ ratios with increasing stage of decomposition 


\section{A Hg concentration}

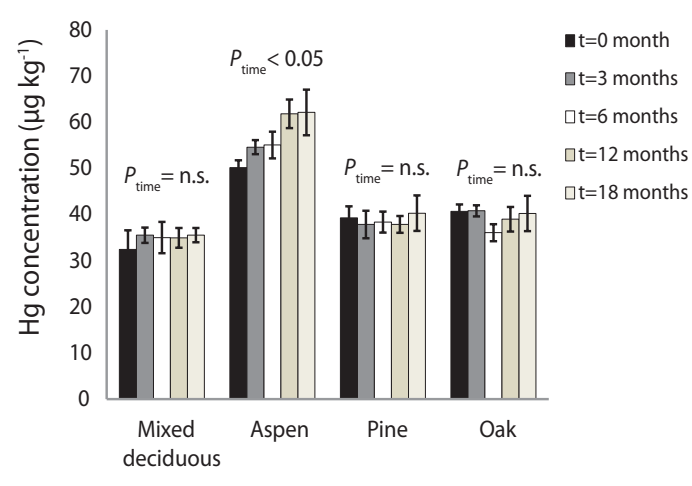

Litter Species

B Hg mass

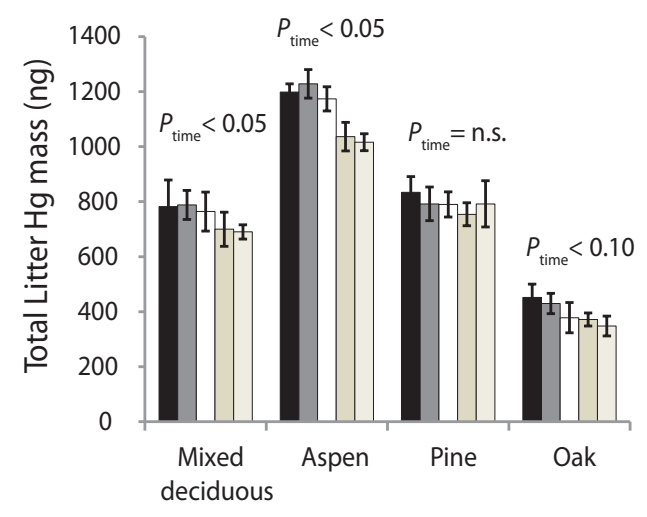

Litter Species

C $\mathrm{Hg} / \mathrm{C}$ ratio

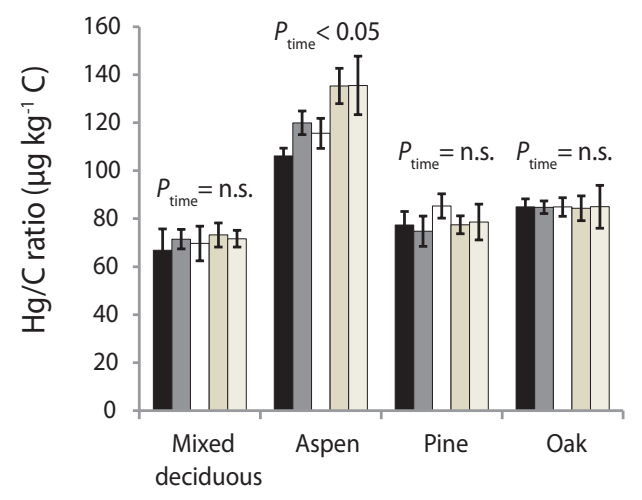

Litter Species

Fig. 2. Development of $\mathrm{Hg}$ concentration, $\mathrm{Hg}$ mass, and $\mathrm{Hg} / \mathrm{C}$ ratio throughout the 18 months of litter decomposition in the controlled laboratory study. Bars represent means \pm standard deviations of five replicate samples. $P$-values are effects of Time for individual species based on Bonferroni post-hoc analyses (Table 2). (see discussion below). Figure 3c shows that for field samples of mixed deciduous and oak litter, $\mathrm{Hg}$ concentrations fall above the regression line between $\mathrm{Hg}$ concentrations and $\mathrm{C} / \mathrm{N}$ ratios of laboratory samples, indicating that even when adjusted for differences in decomposition rates (i.e., $\mathrm{C} / \mathrm{N}$ ratios), field samples show enhanced $\mathrm{Hg}$ levels compared to laboratory samples. However, in aspen and pine litter, data points for field and laboratory samples follow a similar regression line between $\mathrm{Hg}$ and $\mathrm{C} / \mathrm{N}$ ratios.

As with $\mathrm{Hg}$ concentrations, $\mathrm{Hg} / \mathrm{C}$ ratios of field samples were significantly enriched after field exposure (Fig. 3b), and individual analysis showed that the increase was significant in all species but pine. $\mathrm{C} / \mathrm{N}$ levels decreased significantly during exposure in the field in all litter species, with the strongest decrease observed in mixed deciduous, aspen, pine, and to a lesser degree in oak. $\mathrm{C} / \mathrm{N}$ ratios of field samples after 12 months of exposure were significantly lower than $\mathrm{C} / \mathrm{N}$ ratios observed in laboratory samples after 12 months of exposure, with field $\mathrm{C} / \mathrm{N}$ ratios decreased by 23 to $42 \%$ compared to those exposed in the laboratory (Fig. 3c; Table 1).

\subsection{Solubility of $\mathrm{Hg}$ in decomposing litter}

Concentrations of soluble $\mathrm{Hg}$ - measured during one-hour exposure of half the harvested samples to $500 \mathrm{ml}$ of $\mathrm{Hg}$-free water and standardized to the amount of dry mass - were highly variable across different litter species (Fig. 4). For example, the initial amount of soluble $\mathrm{Hg}$ per unit of dry litter mass accounted for $0.22 \pm 0.02 \mathrm{ng} \mathrm{g}^{-1}$ in oak litter, but only for $0.07 \pm 0.01 \mathrm{ng} \mathrm{g}^{-1}$ in pine litter. The amount of soluble $\mathrm{Hg}$ generally decreased in all species throughout the experiment (Fig. 4). After 18 months, concentrations of soluble $\mathrm{Hg}$ were negligible and mainly below the detection limit of the analyzer $\left(\sim 0.5 \mathrm{ng}^{-1}\right.$, based on three times standard deviation of reagent blanks), except in mixed deciduous litter. Overall, ANOVA tests showed significant effects of Time and Species on soluble Hg per unit of dry litter mass (both when only samples above the detection limit were considered and when samples below the detection limit were considered as zero values; Table 2). ANOVA tests indicated no Time $\times$ Species interaction when only samples above the detection limits were considered, but indicated species-specific responses when all samples were considered (i.e., samples below detection limit set as zero), with Post-hoc Bonferroni tests showing significant Time effects in mixed deciduous, aspen, and oak litter, but not in pine litter (Table 2).

\section{Discussion}

\subsection{Changes in dry mass as well as concentration and mass changes of $\mathrm{C}$ and $\mathrm{N}$}

Significant dry mass losses, with relatively consistent temporal decreases in all four litter species through time (Fig. 1), show that sampling replications and time of exposure (i.e., 
A

Hg concentration - Field

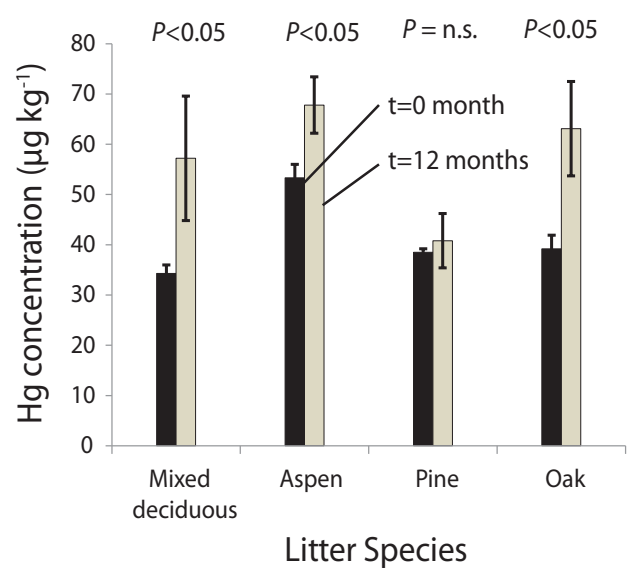

B $\mathrm{Hg} / \mathrm{C}$ ratio - Field

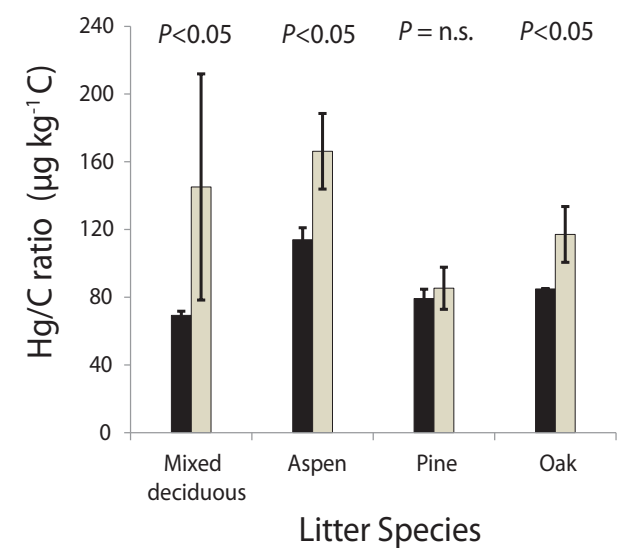

C Hg concentration versus $\mathrm{C} / \mathrm{N}$ ratio - Laboratory and Field

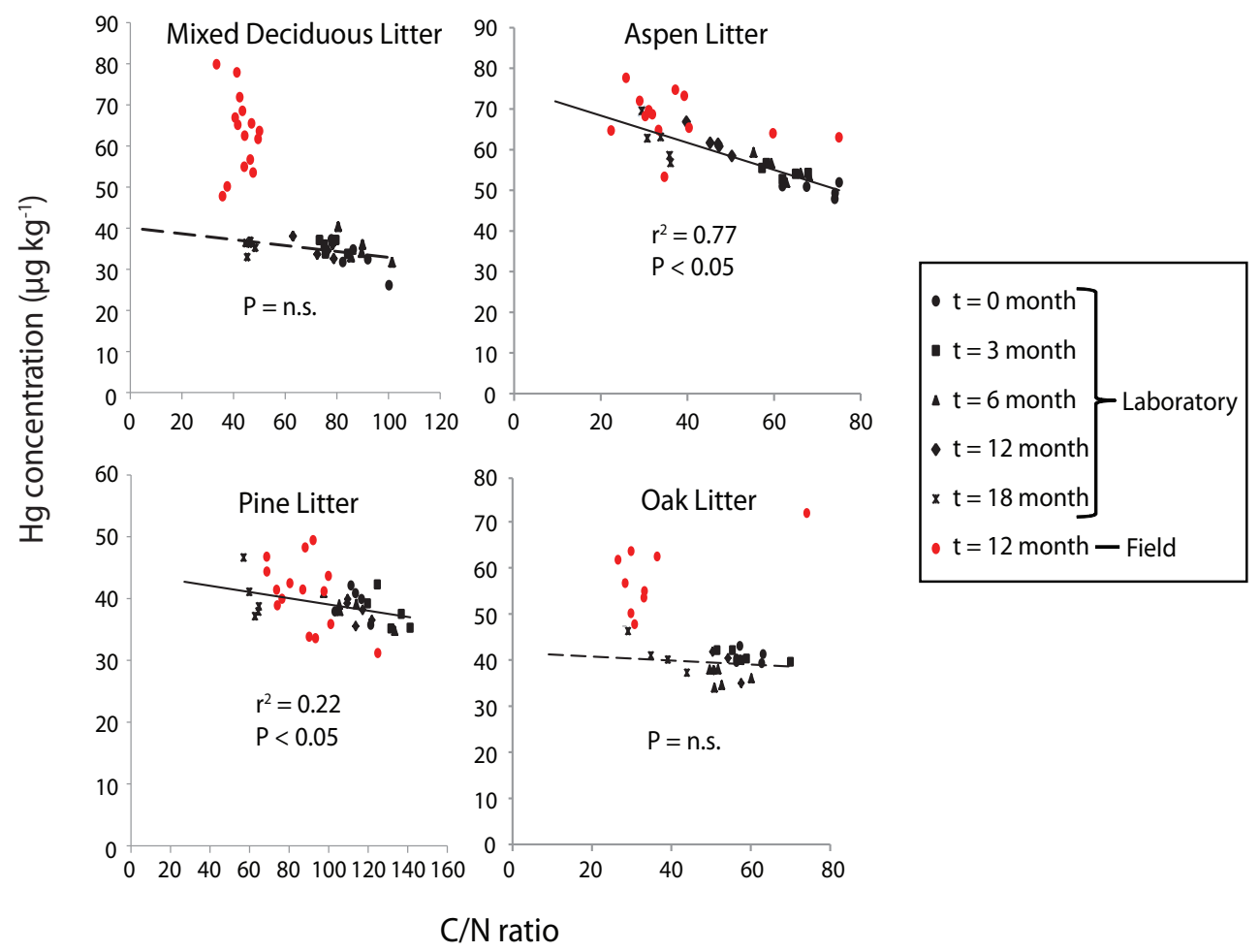

Fig. 3. (A): Hg concentrations of field samples prior to $(t=0$ month $)$ and after $(t=12$ months) one year of exposure in the field. Bars represent means \pm standard deviations of 15 replicate samples. $P$-values are based on paired t-tests. (B): same as panel A for $\mathrm{Hg} / \mathrm{C}$ ratios. (C): scatter plots of $\mathrm{Hg}$ concentration and $\mathrm{C} / \mathrm{N}$ ratios of all litter samples in the laboratory decomposition study (black symbols). Samples at different harvest times are marked with different symbols. Regression line marks linear trendline (solid line when $P<0.05$ ) between $\mathrm{Hg}$ and $\mathrm{C} / \mathrm{N}$ ratios in laboratory samples. Red symbols are $\mathrm{Hg}$ concentrations, and $\mathrm{C} / \mathrm{N}$ ratios of samples exposed in the field. In two species, points fall clearly above trendlines for laboratory samples.

18 months) yielded substantial and detectable mass losses during the laboratory incubation study. Rates of mass decreases were different among litter species, and aspen leaf litter showed the strongest dry mass decrease $(31 \%$ after
18 months) while pine litter showed only small losses (8\%). Many field studies have shown that different litter types are subject to different decomposition rates. For example, studies have shown that deciduous litter decomposed faster than 


\section{Soluble $\mathrm{Hg}$}

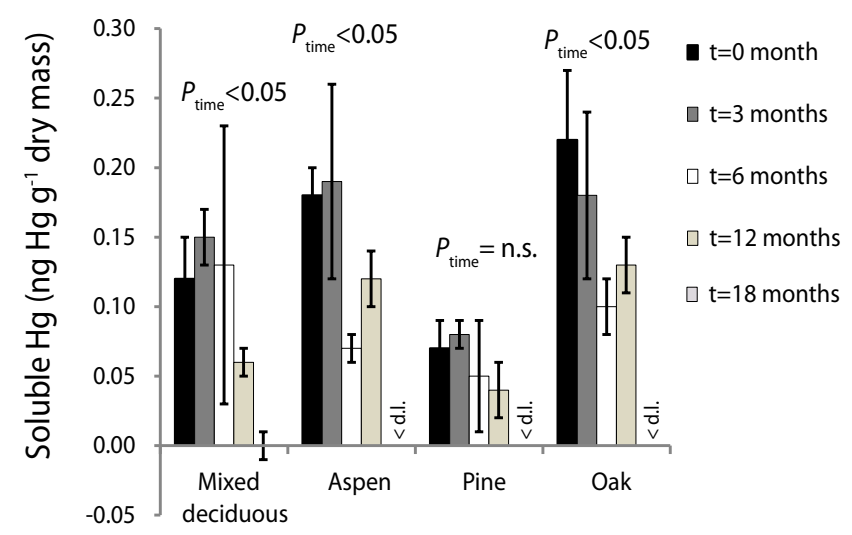

Litter Species

study, the highest $\mathrm{C} / \mathrm{N}$ ratios were observed in pine litter. This is similar to other studies that reported higher $\mathrm{C} / \mathrm{N}$ ratios of coniferous trees over deciduous (Finzi et al., 1998; Smolander et al., 2005), and may be linked to its correspondingly slow decomposition rate and low $\mathrm{N}$ availability. (Webster and Benfield, 1986; Bryant et al., 1998).

\subsection{Concentration and mass changes of $\mathrm{Hg}$ plus stoichiometric relationships to $\mathbf{C}$ and $\mathbf{N}$}

Across all litter types, litter incubated under controlled laboratory conditions exhibited significant $\mathrm{Hg}$ mass losses through time (Fig. 2), with losses after 18 months ranging from 5 to $23 \%$ of the initial $\mathrm{Hg}$ mass present at the start of the experiment. We ensured that all dry mass was harvested from sample jars and was well homogenized prior to analysis; even if small fractions of dry mass were lost during harvests, any losses would have been constant throughout the experiment (i.e., including at the initial harvest at time $=0$ months) and hence would not likely explain mass losses in time. Hg losses were relatively consistent and linear in time. At the level of individual species (post-hoc test after ANOVA), significant mass losses were observed in the three deciduous species but were not significant in pine litter. The lack of mass loss in pine may be associated with its correspondingly slow rate of decomposition.

Because litter samples were kept in glass jars that only alSt. Louis, 2004), while others found the opposite (Demers et al., 2007). Some studies observed inconsistent trends or time-dependent trends, e.g., where initial differences between litter species disappeared during longer time periods (Moore et al., 1999; Sundarapandian and Swamy, 1999; Prescott et al., 2000). In general, these field studies showed higher mass losses (e.g., up to full mass loss after one year; Sundarapandian and Swamy, 1999) than we observed during our controlled laboratory study. Possible reasons for the slower decomposition rates in the laboratory study include an artificial environment without presence of underlying soil substrates, which may have reduced diversity and mass of microbial communities (Couteaux et al., 1995). Although we regularly watered samples every 2-3 weeks, the moisture conditions for mineralization (Horner et al., 1988) may have been unfavorable compared to a field environment as well. Associated with dry mass losses, we observed similar losses of $\mathrm{C}$ mass, although $\mathrm{C}$ mass losses were less consistent in time. C concentrations did not significantly change throughout the experiment, and remained within 97 to $102 \%$ of the original C levels after 18 months of decomposition.

Lower $\mathrm{C} / \mathrm{N}$ ratios in the field control samples (Fig. 3c) compared to laboratory samples after one year of decomposition suggest that litter samples experienced higher decomposition rates under field conditions than during laboratory incubation. $\mathrm{C} / \mathrm{N}$ ratios reflect the degree of decomposition with high $\mathrm{C} / \mathrm{N}$ ratios associated with fresh and undecomposed organic $\mathrm{C}$, while lower $\mathrm{C} / \mathrm{N}$ ratios are indicative of older and more decomposed fractions (Paul and Clark, 1989). In our lowed mass losses by air exchange through a $0.2 \mu \mathrm{m}$ Teflon ${ }^{\circledR}$ filter membrane in the lid, we attribute the observed $\mathrm{Hg}$ mass losses from litter to gaseous evasion to the atmosphere, most likely in elemental form. We originally hypothesized (Hypothesis 1) that $\mathrm{C}$ mass loss due to mineralization $\left(\right.$ as $\left.\mathrm{CO}_{2}\right)$ would result in corresponding losses of $\mathrm{Hg}$ associated with organic $\mathrm{C}$, and our experimental results are in support of this hypothesis. Percentage Hg mass losses, however, were generally smaller than observed dry mass and $\mathrm{C}$ losses; for example, $\mathrm{Hg}$ mass losses after 18 month were $12 \%, 15 \%$, and $5 \%$, compared to dry mass losses of $19 \%, 31 \%$, and $8 \%$ (percentage loss of original mass). The percentage Hg mass lost per unit $\mathrm{C}$ loss in these three litter species was between 48 to $63 \%$. Only in oak litter did we observe almost identical mass losses of dry mass and $\mathrm{Hg}$ mass (i.e., $100 \% \mathrm{Hg}$ lost per dry mass loss). Differences among species indicate that ratios of $\mathrm{Hg}$ subject to evasion versus retention is speciesspecific, a notion also supported by observed $\mathrm{Hg}$ concentration changes in time: ANOVA results showed overall significant Time and Time $\times$ Species effects on Hg concentration, but post-hoc tests showed that the Time trend was driven by one litter species only (aspen) that showed a significant increase in $\mathrm{Hg}$ concentration ( $+24 \%$ of the original concentration after 18 months). $\mathrm{Hg}$ concentrations of the other litter species remained close to starting levels (within 1 to $10 \%$ ). Aspen litter also showed the lowest fraction of $\mathrm{Hg}$ loss, consistent with a $\mathrm{Hg}$ concentration increase in time. We conclude that dry and $\mathrm{C}$ mass are preferentially lost over $\mathrm{Hg}$ 
mass during decomposition in most species (in support of Hypothesis 2), but that losses can be similar in others (e.g., aspen).

Evaporation of gaseous $\mathrm{Hg}$ from soils and surface litter is considered an important source of $\mathrm{Hg}$ to the atmosphere; and many studies have quantified such emissions, in particular from soils, along with its controlling factors (Hanson et al., 1995; Carpi and Lindberg, 1997; Gustin et al., 1997; Poissant and Casimir, 1998; Engle et al., 2001; Zhang et al., 2001; Ericksen and Gustin, 2004; Xin and Gustin, 2007; Kuiken et al., 2008a, b). Only a few studies have performed corresponding measurements of both $\mathrm{Hg}^{0}$ and $\mathrm{CO}_{2}$ efflux rates in order to assess potential relationships between $\mathrm{C}$ mineralization and $\mathrm{Hg}$ emissions, and to quantify if and to what degree $\mathrm{Hg}$ emissions may be due to loss of the organic $\mathrm{C}$ matrix with which $\mathrm{Hg}$ is associated. Fritsche et al. (2008a) reported correlations between $\mathrm{Hg}^{0}$ and $\mathrm{CO}_{2}$ emissions from soils upon stimulation and inhibition of soil respiration using experimental treatments. Wickland et al. (2006) reported a correlation between in situ field soil respiration and $\mathrm{Hg}^{0}$ emission rates in boreal forest soils. Previously, Rogers and McFarlane (1979) reported declines in $\mathrm{Hg}^{0}$ emissions following soil sterilization, albeit without directly measuring $\mathrm{CO}_{2}$ respiration rates. Obrist et al. (2010) observed relationships between $\mathrm{CO}_{2}$ and $\mathrm{Hg}^{0}$ efflux rates in controlled laboratory studies and also showed that $\mathrm{Hg} / \mathrm{C}$ ratios in surface emission only accounted for $\sim 3 \%$ of the $\mathrm{Hg} / \mathrm{C}$ ratio present in soils. They also showed that experimental treatments (such as implementation of anaerobic conditions) easily disrupted this $\mathrm{CO}_{2}-\mathrm{Hg}^{0}$ flux relationship. Significant $\mathrm{Hg}$ mass losses observed in the present laboratory study suggested that gaseous losses of $\mathrm{Hg}$ during decomposition potentially may be much larger in litter than relatively small $\mathrm{Hg}$ losses associated with mineralization in soils. We propose that a significant fraction of $\mathrm{Hg}$ associated with surface forest litter - ranging from $48 \%$ to full loss and depending on species - may be subject to evaporation losses once litter is subject to decomposition, at least under the conditions implemented in our controlled laboratory study.

Our observations of significant $\mathrm{Hg}$ mass losses, and relatively constant $\mathrm{Hg}$ concentrations and $\mathrm{Hg} / \mathrm{C}$ ratios, during decomposition contrast observations made in the field, both from previous studies and our field control. Demers et al. (2007) observed that total litter Hg increased by $134 \%$ and $128 \%$ of its initial mass in deciduous and coniferous litter after two years of exposure in a mixed deciduous and coniferous forest, while at the same time litter dry mass decreased by $33 \%$ and $43 \%$, respectively. Similarly, Hall and St. Louis (2004) reported that $\mathrm{Hg}$ mass in deciduous and coniferous litter exposed in forests increased by $147 \%$, and $37 \%$ compared to initial $\mathrm{Hg}$ mass after the 798 days of decomposition in a boreal, upland forest, while dry mass declined by 57 to $46 \%$, respectively. Hayes et al. (1998) showed no $\mathrm{Hg}$ mass change in spruce litter in the field during $2.5 \mathrm{yr}$ of exposure, despite 20 to $40 \%$ dry mass losses.
Along with Hg mass increases, Hall and St. Louis (2004) observed $\mathrm{Hg}$ concentration increases during field exposure (151 to $474 \%$ after 798 days of field exposure), and Demers et al. (2007) observed $\mathrm{Hg}$ concentration increases of 109 to $127 \%$ after two years of field exposure. In our study, field control samples exposed at the respective sampling locations showed consistently higher $\mathrm{Hg}$ concentrations and higher $\mathrm{Hg} / \mathrm{C}$ ratios after one year compared to levels observed prior to field exposure. Also, litter $\mathrm{Hg}$ concentrations were enhanced by 8 to $+64 \%$ compared to samples incubated for the same time period in the laboratory (Fig. 3a). We graphed $\mathrm{Hg}$ concentrations versus respective $\mathrm{C} / \mathrm{N}$ ratios (Fig. $3 \mathrm{c}$ ) to quantify $\mathrm{Hg}$ concentration changes per unit change $\mathrm{C} / \mathrm{N}$ ratio. As discussed above, we thereby use $\mathrm{C} / \mathrm{N}$ ratios as a relative measure of the degree of decomposition, with higher $\mathrm{C} / \mathrm{N}$ ratios representing less decomposed litter samples and lower $\mathrm{C} / \mathrm{N}$ ratios indicative of more decomposed litter samples. We thereby can account for potentially different decomposition rates of field and laboratory samples and "standardize" $\mathrm{Hg}$ concentrations to the degree of decomposition. Results show that two species (mixed deciduous and oak litter) showed particularly pronounced $\mathrm{Hg}$ concentration enhancements in the field compared to the laboratory, as evident by data points above the linear trendline drawn for laboratory samples. In aspen litter, however, where we already observed $\mathrm{Hg}$ concentration enhancement in the laboratory, the regression line was similar between laboratory and field samples, and in pine litter we observed inconsistent and variable patterns.

The above patterns suggest pronounced sorption of additional $\mathrm{Hg}$ in litter exposed in the field (in support of Hypothesis 3), leading to over $60 \%$ concentration enhancements in the field compared to litter exposed in the laboratory where atmospheric $\mathrm{Hg}$ inputs were minimized by $0.2 \mu \mathrm{m}$ Teflon ${ }^{\circledR}$ membranes covering litter jars and addition of $\mathrm{Hg}$-free water. Our results, however, also indicate that $\mathrm{Hg}$ accumulation in the field may strongly dependent on litter types or on location of field exposure. We did not directly measure $\mathrm{Hg}$ deposition at the field sites, but National Atmospheric Deposition Program data indicate that wet deposition in the area of our field sites ranged between 4 to $6 \mu \mathrm{g} \mathrm{Hg} \mathrm{m}^{-2} \mathrm{yr}^{-1}$ (NADP, 2009). Additional $\mathrm{Hg}$ deposition can be expected in forest sites due to throughfall deposition (Iverfeldt, 1991; St. Louis et al., 2001; Lindberg, 1996) and dry deposition (Driscoll et al., 2007; Lyman et al., 2007; Selin et al., 2007). Previous litter studies have attributed increases in $\mathrm{Hg}$ concentrations in the field to significant sorption of $\mathrm{Hg}$ from the surrounding environment (e.g., Hall and St. Louis, 2004; Demers et al., 2007), although these studies have not looked at the potential for "internal" $\mathrm{Hg}$ accumulation due to preferential losses of $\mathrm{C}$ over $\mathrm{Hg}$ in decomposing litter. Our field and laboratory comparisons support the notion that sorption of $\mathrm{Hg}$ in field litter is the main reason for $\mathrm{Hg}$ accumulation in litter, although our results also suggest that preferential release of $\mathrm{C}$ over $\mathrm{Hg}$ leads to additional "internal" $\mathrm{Hg}$ accumulation in 
some species. Further, it is possible that tissues in the field equilibrate $\mathrm{Hg}$ concentrations with those of the surrounding substrates: Hall and St. Louis (2004) observed that litter with initial $\mathrm{Hg}$ concentration of less than $30 \mathrm{ng} \mathrm{g}^{-1}$ showed increases in $\mathrm{Hg}$ concentration, while litter with $\mathrm{Hg}$ concentrations more than $30 \mathrm{ng} \mathrm{g}^{-1}$ generally showed a decrease compared to initial concentration. In our study, we did not find indication for such a "compensation" point. The notion of significant sorption of $\mathrm{Hg}$ in decomposing litter is in good agreement with many studies that report strong accumulation of $\mathrm{Hg}$ in litter and surface soil layers in the field (Mierle, 1990; Aastrup et al., 1991; Nater and Grigal, 1992; Munthe et al., 1998; Grigal, 2003; Friedli et al., 2007; Obrist et al., 2011).

It is important to note that artificial laboratory conditions also may have contributed to differences between laboratory and field litter samples, including different temperatures, solar radiation, humidities, and differences in watering (e.g., Millipore water versus rainwater, drying-wetting cycles). For example, laboratory samples were kept under darkness while litter samples in the field may have experienced light exposure. Laboratory samples hence may have been shielded from photoreduction processes (e.g., Graydon et al., 2008). This effect, however, actually should have decreased Hg levels of field-exposed litter. Light exposure may possibly only affect very top-surface leaves and may be important for short time periods (until burial by new leaves). Light exposure also may play a role in litter decomposition (e.g., through reduction in litter decomposition rate; Austin and Vivanco, 2006).

We observed pronounced differences in $\mathrm{Hg}$ accumulation patterns between the four litter species; for example, aspen litter showed $\mathrm{Hg}$ concentration increases both in the field and during laboratory exposure, while pine litter showed a lack of accumulation under both exposures. This may be caused by pine litter's low decomposition rate (note its slow mass loss in Fig. 1), possibly caused by relatively high $\mathrm{C} / \mathrm{N}$ ratios as discussed above. Previous studies have shown strong links between $\mathrm{Hg}$ concentrations and organic matter degradation in soils and lake sediments (Grondin et al., 2005; Teisserenc et al., 2011). Obrist et al. (2011) observed increasing Hg accumulation in litter and soils from southern to northern latitudes using data of 14 forest sites, which they attribute in part to potentially slower decomposition rates - and hence longer exposure - of organic carbon pools in northern latitudes. Given that we only evaluated four litter types, it is not possible to assess if $\mathrm{Hg}$ accumulation patterns are specific to particular litter types (such as coniferous versus deciduous litter). Aside from $\mathrm{C} / \mathrm{N}$ ratios, for example, litter species differ in many other biogeochemical processes (tanning and lignin contents, mineralization rates, microbial biomass, dissolved C and N dynamics; Finzi et al., 1998; Côté et al., 2000; Smolander et al., 2005), and such parameters could affect the capacity of litter to retain and sorb $\mathrm{Hg}$.

\subsection{Solubility of $\mathrm{Hg}$ in litter during decomposition}

When harvested litter was submerged in water for quantification of $\mathrm{Hg}$ solubility, the amount of soluble $\mathrm{Hg}$ (filtered by $0.45 \mu \mathrm{m}$ membrane) per litter dry mass strongly decreased in time. At the start of the experiment, soluble $\mathrm{Hg}$ averaged between 0.07 and $0.22 \mathrm{ng} \mathrm{Hg} \mathrm{g}^{-1}$ dry mass, depending on species. This amount, although highly variable, decreased to close to detection limit (about $0.05 \mathrm{ng} \mathrm{Hg} \mathrm{g}^{-1}$ dry mass) to $0.13 \mathrm{ng} \mathrm{Hg} \mathrm{g}^{-1}$ dry mass after 12 months. After 18 months, most litter samples showed no soluble Hg concentrations above the detection limit anymore. These results indicate that the fraction of $\mathrm{Hg}$ available for mobilization as soluble $\mathrm{Hg}$ decreases with increasing time of decomposition.

Comparisons of these results with other studies are challenging since we are not aware of studies that addressed $\mathrm{Hg}$ solubility of variously decomposed litter substrates. In a controlled litter incubation study, Tsui et al. (2008) submerged forest litter samples in different stream water for 66 days and observed that soluble $\mathrm{Hg}$ (both total $\mathrm{Hg}$ and methylated $\mathrm{Hg}$ ) in water samples increased significantly with time of exposure. The Tsui et al. study demonstrated that litter in streams and lakes decomposing under hypoxic conditions contribute $\mathrm{Hg}$ to water bodies and showed that the contributions are highly dependent on stream water chemistry. The experimental conditions between Tsui et al.'s study and ours, however, are not comparable - given that we decomposed litter under aerobic conditions and assessed $\mathrm{Hg}$ solubility at the time of harvests, while Tsui et al.'s study assessed the cumulative amount of soluble $\mathrm{Hg}$ released under anaerobic decomposition. In the field, Hall and St. Louis (2004) reported $\mathrm{Hg}$ concentration increases in tree litter submerged in flooded reservoirs whereby litter seemed to reach equilibrium conditions with the surrounding water. In sphagnum tissues, Heyes et al. (1998) and Hall and St. Louis (2004) reported Hg mass losses from litter submerged in wetland and flooded reservoirs, respectively.

Possible reasons for declines in soluble $\mathrm{Hg}$ release with increasing stage of decomposition include gaseous losses of $\mathrm{Hg}$ (see above) that may have depleted $\mathrm{Hg}$ that was initially present in soluble form. Other reasons include the possibility that decomposition may have led to increased surface area as well as increased presence of humic and fulvic substances, which may result in more efficient binding of $\mathrm{Hg}$ in decomposing litter fractions. Allard and Arsenie (1991) showed that humic and fulvic acids have strong sorption capacity for $\mathrm{Hg}$, thereby reducing its mobility, and humic matter is known to play a major role in controlling solubility and mobilization of $\mathrm{Hg}$ in freshwater systems (Mierle and Ingram, 1991; Weber, 1993). Ericksen et al. (2003) showed that about 1.5 to $3 \%$ of total $\mathrm{Hg}$ present in fresh leaves was water soluble and easily rinsed from the leaves. In our study, the fraction of soluble $\mathrm{Hg}$, as a percentage of total $\mathrm{Hg}$, only ranged between 0.2 and $0.6 \%$ at the beginning of the experiment, and this further declined with time. Reasons for reduced solubility 
in our study may include different tissue types, leaf age, and stage of decomposition (e.g., fresh leaves versus surface Oi litter), and that litter was subject to precipitation wash-off prior to collection in the field while leaves used by Ericksen et al. (2003) were grown in environmentally controlled growth chambers without experiencing rain.

\section{Summary}

The results of our laboratory incubation study showing substantial Hg mass losses in decomposing litter are important in regards to atmospheric emissions of $\mathrm{Hg}$ from terrestrial ecosystems. Such releases back into the atmosphere can be considered re-emission fluxes of $\mathrm{Hg}$ that was originally sorbed from the atmosphere and then deposited by leaf litterfall. The issue of re-emission processes is of high interest since thousands of tons of $\mathrm{Hg}$ are contained and stored in surface litter and surface soils (e.g., Grigal et al., 2003; Obrist, 2007), including substantial amounts of past anthropogenic emissions due to increased atmospheric $\mathrm{Hg}$ pollution during the last $150 \mathrm{yr}$ (Fitzgerald et al., 1998; Schuster et al., 2002). Substantial re-emission of $\mathrm{Hg}$ contained in terrestrial storage pools, particularly during mineralization processes, could have important consequences for global environmental change due to predicted changes in terrestrial $\mathrm{C}$ storage (Grigal, 2003; Obrist, 2007). Recent studies using stable isotopes (Hintelmann et al., 2002; Ericksen et al., 2005; Harris et al., 2007; Graydon et al., 2009) showed that most of newly deposited $\mathrm{Hg}$, when applied via wet deposition, is retained in watersheds and soils, and that atmospheric re-emission may account for less than $10 \%$ in the first year after application (Ericksen et al., 2005; Harris et al., 2007). Our study points toward potentially stronger re-emission, up to $23 \%$ of $\mathrm{Hg}$ within 18 months, of $\mathrm{Hg}$ that is originally associated with plant litter. Our study, however, cannot address the degree to which re-emission will reach the atmosphere in the field, or to what degree artificial laboratory conditions might have biased our results. Our laboratory litter samples, for example, were kept in an artificial environment, were removed from soils, kept in darkness, and watered regularly with Millipore water, and all these conditions may affect re-emission losses of $\mathrm{Hg}$. In a field study, for comparison, we found that gaseous $\mathrm{Hg} / \mathrm{C}$ ratios in emissions only accounted for a few percent of the $\mathrm{Hg} / \mathrm{C}$ ratios of the soil pool (Obrist et al., 2009), while in this laboratory study, we observed up to equivalent loss of $\mathrm{Hg}$ and $\mathrm{C}$ upon decomposition in litter. Smith-Downey et al. (2010) estimated the fraction of re-emissions of $\mathrm{Hg}$ released from soil organic carbon upon decomposition to $16 \%$. Our results also indicate that litter types show highly speciesspecific behaviors: evasion losses of $\mathrm{Hg}$ were variable by species (ranging from 5 to $23 \%$ ), and so was sorption of new $\mathrm{Hg}$ litter observed in the field, indicating that different plant tissues show inherently different behaviors regarding sorption, retention, and re-emission of $\mathrm{Hg}$.
Acknowledgements. We would like to thank Rebecca Wenk, Andrew Richardson, Scott Ollinger, Michelle Day, and Rob York for help with litter collection and placement of litter bags in the field. Thanks also to Johnny Dagget, Bill Coulomb, Russ Bergin, So Lee, and Xavier Faïn for the experimental set-up and analytical support. We appreciate editorial comments by Roger Kreidberg. Funding was provided by the US Environmental Protection Agency through a Science-To-Achieve-Results grant (\# RD833378010) and through DRI Internal Project Assignment funding.

Edited by: X. Wang

\section{References}

Aastrup, M., Johnson, J., Bringmark, E., Bringmakr, I., and Iverfeldt, A.: Occurence and transport of mercury within a small catchment area, Water Air Soil Poll., 56, 155-167, 1991.

Allard, B. and Arsenie, I.: Abiotic reduction of mercury by humic substances in aquatic system - an important process for the mercury cycle, Water Air Soil Poll., 56, 457-464, 1991.

Austin, A. T. and Vivanco, L.: Plant litter decomposition in a semiarid ecosystem controlled by photodegradation, Nature, 442 , 555-558, 2006.

Bryant, D. M., Holland, E. A., Seastedt, T. R., and Walker, M. D.: Analysis of litter decomposition in an alpine tundra, Can. J. Bot., 76, 1295-1304, 1998.

Carpi, A. and Lindberg, S. E.: Sunlight-mediated emission of elemental mercury from soil amended with municipal sewage sludge, Environ. Sci. Technol., 31, 2085-2091, 1997.

Côté, L., Brown, S., Pare, D., Fyles, J., and Bauhus, J.: Dynamics of carbon and nitrogen mineralization in relation to stand type, stand age and soil texture in the boreal mixedwood, Soil Biol. Biochem., 32, 1079-1090, 2000.

Couteaux, M. M., Bottner, P., and Berg, B.: Litter decomposition, climate and litter quality, Trends Ecol. Evol., 12, 63-66, 1995.

Demers, J. D., Driscoll, T. C., Timothy, J. F., and Joseph, B. Y.: Mercury cycling in litter and soil in different forest types in the Adirondack region, New York, Ecol. Appl., 17, 1341-1351, 2007.

Driscoll, C. T., Blette, V., Yan, C., Schofield, C. L., Munson, R., and Holsapple, J.: The role of dissolved Organic Carbon in the chemistry and bioavailability of mercury in remote Adirondack lakes, Water Air Soil Poll., 80, 499-508, 1995.

Driscoll, C. T., Han, Y.-J., Chen, C. Y., Evers, D. C., Lambert, K. F., Holsen, T. M., Kamman, N. C., and Munson, R. K.: Mercury contamination in forest and freshwater ecosystems in the Northeastern United States, Bioscience, 57, 17-28, 2007.

Engle, M., Gustin, M. S., and Zhang, H.: Quantifying natural source mercury emissions from the Ivanhoe mining district, NorthCentral Nevada, USA, Atmos. Environ., 35, 3987-3997, 2001.

Ericksen, J. and Gustin, M. S.: Foliar exchange of mercury as a function of soil and air mercury concentrations, Sci. Total Environ., 324, 271-279, 2004.

Ericksen, J. A., Gustin, M. S., Schorran, D. E., Johnson, D. W., Lindberg, S. E., and Coleman, J. S.: Accumulation of atmospheric mercury in forest foliage, Atmos. Environ., 37, 16131622, 2003.

Ericksen, J. A., Gustin, M. S., Lindberg, S. E., Olund, S. D., and Krabbenhoft, D. P.: Assessing the potential for re-emission of 
mercury deposited in precipitation from arid soils using a stable isotope, Environ. Sci. Technol., 39, 8001-8007, 2005.

Finzi, A. C., Van Breemen, N., and Canham, C. D.: Canopy treesoil interactions within temperate forests: species effects on soil carbon and nitrogen, Ecol. Appl., 8, 440-446, 1998.

Fitzgerald, W. F., Engstrom, D. R., Mason, R. P., and Nater, E. A.: The case for atmospheric mercury contamination in remote areas, Environ. Sci. Technol., 32, 1-7, 1998.

Frescholtz, T. F., Gustin, M. S., Schorran, D. E., and Fernandez, G. C. J.: Environmental toxicology - assessing the source of mercury in foliar tissue of quaking aspen, Environ. Toxicol. Chem., 22, 2114-2119, 2003.

Friedli, H. R., Radke, L. F., Payne, N. J., McRae, D. J., Lynham, T. J., and Blake, T. W.: Mercury in vegetation and organic soil at an upland boreal forest site in Prince Albert National Park, Saskatchewan, Canada, Geophys. Res., 112, G01004, doi:10.1029/2005JG000061, 2007.

Fritsche, J., Obrist, D., and Alewell, C.: Evidence of microbial control of $\mathrm{Hg}^{0}$ emissions from uncontaminated terrestrial soils, J. Plant Nutr. Soil Sc., 171, 200-209, 2008a.

Fritsche, J., Obrist, D., Zeeman, M. J., Conen, F., Wugster, W., and Alewell, C.: Elemental mercury fluxes over a sub-alpine grassland with two micrometeorological methods, Atmos. Environ., 42, 2922-2933, 2008b.

Fu, X., Feng, X., Zhu, W., Rothenberg, S., Yao, H., and Zhang, H.: Elevated atmospheric deposition and dynamics of mercury in a remote upland forest of southwestern China, Environ. Pollut., 158, 2324-2333, 2010.

Graydon, J., St. Louis, V., Hintelmann, H., Lindberg, S., Sandilands, K., Rudd, J., Kelly, C., Hall, B., and Mowat, L.: LongTerm Wet and Dry Deposition of Total and Methyl Mercury in the Remote Boreal Ecoregion of Canada, Environ. Sci. Technol., 42, 8345-8351, 2008.

Graydon, J. A., St. Louis, V. L., Hintelmann, H., Lindberg, S. E., Sandilands, K. A., Rudd, J. W. M., Kelly, C. A., Tate, M. T., Krabbenhoft, D. P., and Lehnherr, I.: Investigation of uptake and retention of atmospheric $\mathrm{Hg}$ (II) by boreal forest plants using stable Hg isotopes, Environ. Sci. Technol., 43, 4960-4966, 2009.

Grigal, D. F.: Inputs and outputs of mercury from terrestrial watersheds: a review, Environ. Rev., 10, 1-39, 2002.

Grigal, D. F.: Mercury sequestration in forests and peatlands: a review, J. Environ. Qual., 32, 393-405, 2003.

Grigal, D. F., Kolka, R. K., Fleck, J. A., and Nater, E. A.: Mercury budget of an upland-peatland watershed, Biogeochemistry, 50, 95-109, 2000.

Grondin, A., Lucotte, M., Mucci, A., and Fortin, B.: Mercury and lead profiles and burdens in soils of Quebec (Canada) before and after flooding, Can. J. Fish. Aqat. Sci., 52, 2493-2506, 2005.

Gustin, M. S., Taylor, G. E., and Maxey, R. A.: Effect of temperature and air movement on the flux of elemental mercury from substrate to the atmosphere, J. Geophys. Res.-Atmos., 102, 3891-3898, 1997.

Hall, B. D. and St. Louis, V. L.: Methylmercury and total mercury in plant litter decomposing in upland forests and flooded landscapes, Environ. Sci. Technol., 38, 5010-5021, 2004.

Hanson, P. J., Lindberg, S. E., Tabberer, T. A., Owens, J. G., and Kim, K. H.: Foliar exchange of mercury vapor : evidence for a compensation point, Water Air Soil Poll., 80, 373-382, 1995.

Harris, R. C., Rudd, J. W. M., Amyot, M., Babiarz, C., Beaty, K.
G., Blanchfield, P. J., Bodaly, R. A., Branfireun, B. A., Gilmour, C. C., Graydon, J. A., Heyes, A., Hintelmann, H., Hurley, J. P., Kelly, C. A., Krabbenhoft, D. P., Lindberg, S. E., Mason, R. P., Paterson, M. J., Podemski, C. L., Robinson, A., Sandilands, K. A., Southworth, G. R., St. Louis, V. L., and Tate, M. T.: Wholeecosystem study shows rapid fish-mercury response to changes in mercury deposition, P. Natl. Acad. Sci. USA, 104, 1658616591, 2007.

Heyes, A., Moore, T. R., and Rudd, J. W. M.: Mercury and methylmercury in decomposing vegetation of a pristine and impounded wetland, J. Environ. Qual., 27, 591-599, 1998.

Hintelmann, H., Harris, R., Heyes, A., Hurley, J., Kelly, C., Krabbenhoft, D., Lindberg, S., Rudd, J., Scott, K., and St Louis, V. L.: Reactivity and mobility of new and old mercury deposition in a Boreal Forest ecosystem during the first year of the METAALICUS study, Environ. Sci. Technol., 36, 5034-5040, 2002.

Horner, D. J., Gosz, J. R., and Cates, R. G.: The role of carbonbased plant secondary metabolites in decomposition in terrestrial ecosystems, Am. Nat., 132, 869-883, 1988.

Iverfeldt, A.: Mercury in forest canopy throughfall water and its relation to atmospheric deposition, Water Air Soil Poll., 56, 553$564,1991$.

Johansson, K. and Iverfeldt, Å.: The relation between mercury content in soil and transport of mercury from small catchments in Sweden, in: Mercury Pollution: Integration and Synthesis, edited by: Watras, C. J. and Huckabee, J. W., Lewis publishers, Monterey, California, USA, 323-328, 1994.

Joslin, J. D.: Regional differences in mercury levels in aquatic ecosystems: a discussion of possible causal factors with implications for the Tennessee River system and the Northern Hemisphere, Environ. Manage., 18, 559-567, 1994.

Kaneko, N. and Salamanca, E.: Mixed leaf litter effects on decomposition rates and soil microarthropod communities in an oakpine stand in Japan, Ecol. Res., 14, 131-138, 1999.

Kolka, R. K., Grigal, D. F., Verry, E. S., and Nater, E. A.: Mercury and organic carbon relationships in streams draining forested upland/peatland watersheds, J. Environ. Qual., 28, 766-775, 1999.

Kuiken, T., Gustin, M. S., Zhang, H., Lindberg, S. E., and Sedinge, B.: Mercury emission from terrestrial background surfaces in the eastern USA, Part II: Air/surface exchange of mercury within forests from South Carolina to New England, Appl. Geochem., 23, 356-368, 2008a.

Kuiken, T., Zhang, H., Gustin, M. S., and Lindberg, S.: Mercury emission from terrestrial background surfaced in the eastern USA, Part I: Air/surface exchange of mercury within a southeastern deciduous forest (Tennessee) over one year, Appl. Geochem., 23, 345-355, 2008b.

Lee, Y. H., Bishop, K. H., Munthe, J., Iverfeldt, Å., Verta, M., Parkman, H., and Hultberg, H.: An examination of current $\mathrm{Hg}$ deposition and export in Fenno-Scandinavian catchments, Biogeochemistry, 40, 125-135, 1998.

Lindberg, S. E.: Forest and the global biogeochemical cycle of mercury: the importance of understanding air/vegetation exchange processes, in: Global and Regional Mercury Cycles: Sources, Fluxes and Mass Balances NATOASI Series 21, edited by: Baeyens, W., Ebinghaus, R., and Vasilie, O., Kluwer Academic Publishers, Dordrecht, The Netherlands, 359-380, 1996.

Lindberg, S. E. and Harris, R. C.: Mercury enrichment in estuarine 
plant detritus, Mar. Pollut. Bull., 5, 93-95, 1974.

Lindberg, S. E., Hanson, P. J., Meyers, T. P., and Kim, K. H.: Atmosphere-surface exchange of mercury in a forest: results of modeling and gradient approaches, J. Geophys. Res.-Atmos., 97, 2519-2528, 1992.

Lorey, P. and Driscoll, C. T.: Historical trends of mercury deposition in Adirondack lakes, Environ. Sci. Technol., 33, 718-722, 1999.

Lyman, S. N., Gustin, M. S., Prestbo, E. M., and Marsik, F. J.: Estimation of dry deposition of atmospheric mercury in Nevada by direct and indirect methods, Environ. Sci. Technol., 41, 19701976, 2007.

Mason, R. P. and Sheu, G. R.: Role of the ocean in the global mercury cycle, Global Biogeochem. Cy., 16, 1093, doi:10.1029/2001GB001440, 2002.

Meili, M.: The coupling of mercury and organic matter in the biogeochemical cycle - towards a mechanistic model for the boreal forest zone, Water Air Soil Poll., 56, 333-347, 1991.

Millhollen, A. G., Gustin, M. S., and Obrist, D.: Mercury accumulation in grass and forb species as a function of atmospheric carbon dioxide concentrations and mercury exposures in air and soil, Chemosphere, 65, 889-897, 2006a.

Millhollen, A. G., Obrist, D., and Gustin, M. S.: Foliar mercury accumulation and exchange for three tree species, Environ. Sci. Technol., 40, 6001-6006, 2006b.

Mierle, G.: Aqueous inputs of mercury to Precambrian shield lakes in Ontario, Environ. Toxicol. Chem., 9, 843-851, 1990.

Mierle, G. and Ingram, R.: The role of humic substances in the mobilization of mercury from watersheds, Water Air Soil Poll., 56, 349-357, 1991.

Moore, T. R., Trofymow, J. W., Taylor, B., Prescott, C., Camire, C., Duschene, L., Fyles, J., Kozak, L.,Kranavetter, M., Morrison, I., Siltanesn, M., Smith, S., Titus, B., Visser, S., Wein, R., and Zoltai, S.: Litter decomposition rates in Canadian forests, Glob. Change Biol., 5, 75-82, 1999.

Munthe, J., Lee, Y. H., Hultberg, H., and Iverfeldt, Å., Borg, G. Ch., and Andersson, I.: Cycling of mercury and methylmercury in the Gårdsjön Catchements, in: Experimental Reversal of Acid Rain Effects, The Gårdsjön Roof Project, edited by: Hultberg, H. and Skeffington, R., John Wiley \& Sons, New York, USA, 261-276, 1998.

National Atmospheric Deposition Program: Mercury Deposition Program (NADP), available at: http://nadp.sws.uiuc.edu/mdn/, last access: 11 January 2011, 2009.

Nater, E. A. and Grigal, D. F.: Regional trends in mercury distribution across the Great Lakes states, North Central USA, Nature, 358, 139-141, 1992.

Obrist, D.: Atmospheric mercury pollution due to losses of carbon pools?, Biogeochemistry, 85, 119-123, 2007.

Obrist, D., Conen, F., Vogt, R., Siegwolf, R., and Alewell, C.: Estimation of $\mathrm{Hg}^{0}$ exchange between ecosystems and the atmosphere using ${ }^{222} \mathrm{Rn}$ and $\mathrm{Hg}^{0}$ concentration changes in the stable nocturnal boundary layer, Atmos. Environ., 40, 856-866, 2006.

Obrist, D., Johnson, D. W., and Lindberg, S. E.: Mercury concentrations and pools in four Sierra Nevada forest sites, and relationships to organic carbon and nitrogen, Biogeosciences, 6, 765777, doi:10.5194/bg-6-765-2009, 2009.

Obrist, D., Faïn, X., and Berger, C.: Relationships between gaseous elemental mercury emissions and $\mathrm{CO}_{2}$ respiration rates in ter- restrial soils under aerobic and anaerobic conditions, Sci. Total Environ., 408, 1691-1700, 2010.

Obrist, D., Johnson, D. W., Lindberg, S. W., Luo, Y., Hararuk, O., Bracho, R., Battles, J. J., Dail, D. B., Edmonds, R. L., Monson, R. K., Ollinger, S. V., Pallardy, S. G., Pregitzer, K. S., and Todd, D. E: Mercury distribution across 14 U.S. forests, Part I: Spatial patterns of total $\mathrm{Hg}$ concentrations in biomass, litter, and soils, Environ. Sci. Technol., 45, 3974-3981, 2011.

Paul, E. A. and Clark, F. E.: Soil microbiology and biochemistry, Academic Press, San Diego, California, USA, ISBN 0125468059, 1989.

Poissant, L. and Casimir, A.: Water-air and soil-air exchange rate of total gaseous mercury measured at background sites, Atmos. Environ., 32, 883-893, 1998.

Prescott, C. E., Zabek, L. M., Staley, C. L., and Kabzems, R.: Decomposition of broad leaf and needle litter in forests of British Columbia: influences of litter type, forest type, and litter mixtures, Can. J. Forest Res., 30, 1742-1750, 2000.

Rea, A. W., Lindberg, S. E., and Keeler, G. J.: Assessment of dry deposition and foliar leaching of mercury and selected trace elements based on washed foliar and surrogate surfaces, Environ. Sci. Technol., 34, 2418-2425, 2000.

Rea, A. W., Lindberg, S. E., Scherbatskoy, T., and Keeler, G. J.: Mercury accumulation in foliage over time in two northern mixed hardwood forests, Water Air Soil Poll., 133, 49-67, 2002.

Rogers, R. D. and McFarlane, J. C.: Factors influencing the volatilization of mercury from soil, J. Environ. Qual., 8, 255260, 1979.

Rutter, A. P., Schauer, J. J., Shafer, M. M., Creswell, J. E., Olson, M. R., Robinson, M., Collins, R. M., Parman, A. M., Katzman, T. L., and Mallek, J. L.: Dry deposition of gaseous elemental mercury to plants and soils using mercury stable isotopes in a controlled environment, Atmos. Environ., 45, 848-855, 2011.

Schuster, P. F., Krabbenhoft, D. P., and Naftz, D. L.: Atmospheric mercury deposition during the last 270 years: a glacial ice core record of natural and anthropogenic sources, Environ. Sci. Technol., 36, 2303-2310, 2002.

Schwesig, D. and Matzner, E.: Pools and fluxes of mercury and methylmercury in two forested catchments in Germany, Sci. Total Environ., 260, 213-223, 2000.

Selin, N. E., Jacob, D. J., Park, R. J., Yantosca, R. M., Strode, S., Jaegle, L., and Jaffe, D.: Chemical cycling and deposition of atmospheric mercury: global constraints from observations, J.Geophys. Res., 112, D02308, doi:10.1029/2006JD007450, 2007.

Sheehan, K. D., Fernandez, I. J., Kahl, J. S., and Amirbahman, A.: Litterfall mercury in two forested watersheds at Acadia National Park, Maine, USA, Water Air Soil Poll., 170, 249-265, 2006.

Smith-Downey, N. V., Sunderland, E. M., and Jacob, D. J.: Anthropogenic impacts on global storage and emissions of mercury from terrestrial soils: Insights from a new global model, J. Geophys. Res., 115, G03008, doi:10.1029/2009JG001124, 2010.

Smolander, A., Loponen, J., Suominen, K., and Kitunen, V.: Organic matter characteristics and $\mathrm{C}$ and $\mathrm{N}$ transformations in the humus layer under two tree species, Betula pendula and Picea abies, Soil. Biol. Biochem., 37, 1309-1318, 2005.

Stamenkovic, J. and Gustin, M. S.: Non-stomatal versus stomatal uptake of atmospheric mercury, Environ. Sci. Technol., 43, 1367-1372, 2009. 
St. Louis, V., Rudd, J. W. M., Kelly, C. A., Hall, B. D., Rolfhus, K. R., Scott, K. J., Lindberg, S. E., and Dong, W.: Importance of the forest canopy to fluxes of methyl mercury and total mercury to boreal ecosystems, Environ. Sci. Technol., 35, 3089-3098, 2001.

Sundarapandian, S. M. and Swamy, P. S.: Litter production and leaf litter decomposition of selected tree species in tropical forest at Kodayar in the Western Ghats, India, Forest Ecol. Manag., 123, 231-244, 1999.

Teisserenc, R., Lucotte, M., and Houel, S.: Terrestrial organic matter biomarkers as tracers of $\mathrm{Hg}$ sources in lake sediments, Biogeochemistry, 103, 235-244, 2011.

Tsui, M. T. K., Finlay, J. C., and Nater, E. A.: Effects of stream water chemistry and tree species on release and methylation of mercury during litter decomposition, Environ. Sci. Technol., 42, 8692-8697, 2008.

Weber, J. H.: Review of possible paths for abiotic methylation of mercury (II) in the aquatic environment, Chemosphere, 26, 2063-2077, 1993.
Webster, J. R. and Benfield, E. F.: Vascular plant breakdown in freshwater ecosystems, Annu. Rev. Ecol. Syst., 17, 567-594, 1986.

Wickland, K., Krabenhoft, D., and Olund, S.: Evidence for a link between soil respiration and mercury emissions from organic soils, Eighth International Conference on Mercury as a Global Pollutant, Madison, Wisconsin, 6-11 August 2006.

Xin, M. and Gustin, M. S.: Gaseous elemental mercury exchange with low mercury containing soils: investigation of controlling factors, Appl. Geochem., 22, 1451-1466, 2007.

Zhang, H., Lindberg, S. E., Marsik, F. J., and Keeler, G. J.: Mercury air/surface exchange kinetics of background soils of the Tahquamenon River watershed in the Michigan Upper Peninsula, Water Air Soil Poll., 126, 151-169, 2001.

Zhang, L., Wright, L. P., and Blanchard, P.: A review of current knowledge concerning dry deposition of atmospheric mercury, Atmos. Environ., 43, 5853-5864, 2009. 